\title{
Depletion of Streamflow
}

By Infiltration in the

Main Channels of

The Tucson Basin,

Southeastern Arizona

GEOLOGICAL SURVEY WATER-SUPPLY PAPER 1939-B

Prepared in cooperation with the city of Tucson, the U.S. Bureau of Reclamation, and the University of Arizona

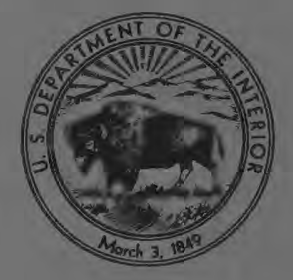





\section{Depletion of Streamflow}

By Infiltration in the

Main Channels of

The Tucson Basin,

\section{Southeastern Arizona}

By D. E. BURKHAM

WATER RESOURCES OF THE TUCSON BASIN

GEOLOGICAL SURVEY WATER-SUPPLY PAPER 1939-B

Prepared in cooperation with the city of Tucson, the U.S. Bureau of Reclamation, and the University of Arizona

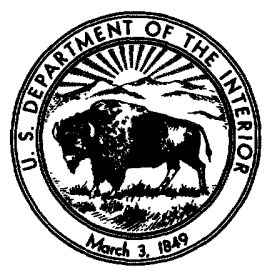


UNITED STATES DEPARTMENT OF THE INTERIOR

WALTER J. HICKEL, Secretary

GEOLOGICAL SURVEY

William T. Pecora, Director

Library of Congress catalog-card No. 72-608484 


\section{CONTENTS}

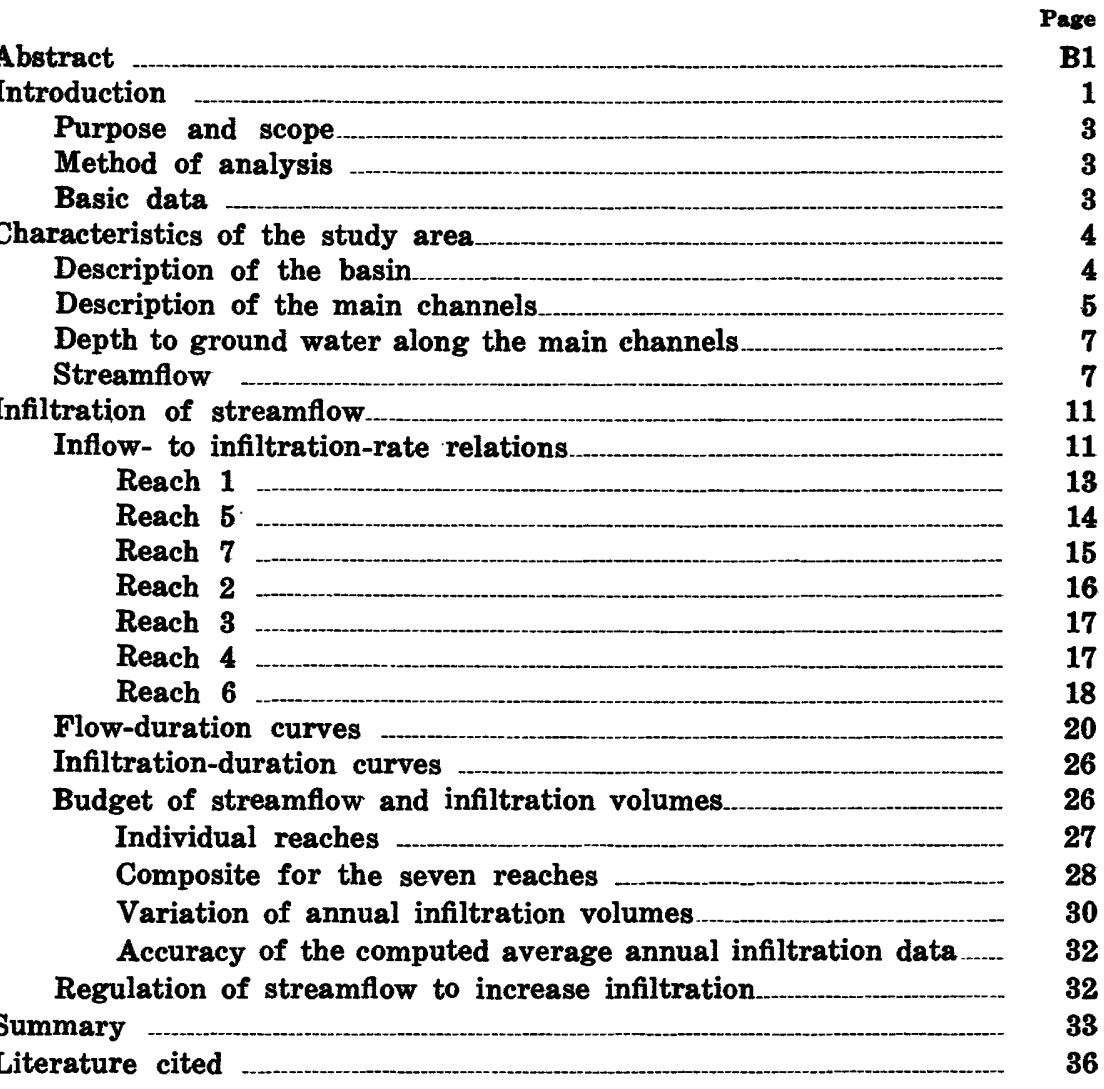

\section{ILLUSTRATIONS}

Plate 1. Map showing instrumentation and reaches studied,

Tucson basin, southeastern Arizona_._. In pocket

Figure 1. Index map of Arizona showing location of report area__ B2

2-11. Graphs showing:

2. Relation between sediment size and depth at seven sites along the Santa Gruz River from Continental to Cortaro, Ariz

3. Relation between sediment size and depth at three sites along Pantano Wash from Vail to the mouth

4. Relation between sediment size and depth at three sites along Rillito Creek from Pantano Wash to the mouth 
Figures 2-11. Graphs showing-Continued

5. Relation between inflow rates and infiltration rates for the 28.5-mile reach 1, Santa Cruz River from Continental to Tucson, Ariz

6. Relation between inflow rates and infiltration rates for the 9.5-mile reach 5, Tanque Verde Creek at Sabino Canyon road to Rillito Creek near Tucson gaging station

7. Relation between inflow rates and infiltration rates for the 12.25-mile reach 7, Santa Cruz River at Tueson to Santa Cruz River at Cortaro, Ariz......

8. Relation between inflow rates and infiltration rates for the 3.2-mile reach of Agua Caliente Wash from Tanque Verde road crossing to Soldiers Canyon and for the 4.2-mile reach of Tanque Verde Creek from Tanque Verde Loop road to Tanque Verde road

9. Relation between inflow rates and infiltration rates for the 4.8-mile reach of Rincon Creek from the Rincon Creek near Tucson gaging station to Camino Loma Alta and for the 3.0-mile reach of Rincon Creek from Camino Loma Alta to Old Spanish Trail

10. Relation between daily discharge and size of drainage basin in the Tucson basin

11. Flow duration for tributary 1-4 and infiltration duration as water moves down the Santa Cruz River from mouth of 1-4 to Santa Cruz River at Tucson, Ariz

\section{TABLES}

TABLE 1. Streamflow-gaging stations in or near the Tucson basin

2. Characteristics of the seven study reaches of the main channels, Tucson basin

3. Water budget of average annual measured or synthesized streamflow and synthesized infiltration volumes (1936-63) for the seven reaches of the main channels, Tucson basin

4. Water budget of average annual synthesized streamflow and infiltration volumes for the main channels of the Tucson basin (1936-63)

5. Percentage of total average annual infiltration of inflow in the seven reaches, $1936-63$

6. Maximum possible increase in infiltration by total regulation of inflow from different sources in the Tucson basin.-

7. Average annual inflow, infiltration, outflow, and maximum possible increase in infiltration by total regulation of inflow in the Tucson basin. 
WATER RESOURGES OF THE TUGSON BASIN

\title{
DEPLETION OF STREAMFLOW BY INFILTRATION IN THE MAIN CHANNELS OF THE TUCSON BASIN, SOUTHEASTERN ARIZONA
}

\author{
By D. E. BURKHAM
}

ABSTRACT

Estimates were made of the average annual volume of infiltration for the period 1936-63 along seven normally dry alluvial channels in the Tucson basin. The essential parts of the method used to estimate infiltration were (1) average relation between rates of inflow and infiltration and (2) flowduration curves of streamflow. The end product is an inflltration-duration curve from which the average annual volume of infiltration may be computed. The general empirical relation between inflow rates and infiltration rates for a reach of channel is

$$
\text { infiltration rate }=C \text { (inflow rate) }{ }^{0.8} \text {, }
$$

in which $C$ is a variable coefficient. In this report an average coefficient was determined or estimated for all flow moving through a given reach of channel. The equation is used in estimating the infiltration rate only when the inflow rate is greater than the computed infiltration rate. Estimates of flow duration for ungaged streams were derived from simple relations between measured daily streamflow and size of contributing basin for flow that is equaled or exceeded $0.1,0.5,2.0$, and 10 percent of the time. The degree of correlation between measured streamflow and size of basin is fair for flows of rare occurrence but decreases with more common flows.

The main channels in the Tucson basin are efficient natural infiltration galleries. The average annual streamflow depletion ranged from about 30 to 90 percent of the average annual inflow to the seven reaches for the period 1936-63. The average annual inflow to all the reaches was about 66,000 acrefeet; of this about 47,000 acre-feet, or 70 percent, was depleted by infiltration, and about 19,000 acre-feet flowed out of the basin.

The annual variation in infiltration volumes along the main channels is large and is mainly the result of variation in streamflow. On the basis of streamflow data, the extremes in the annual volumes of infiltration are estimated to range from near zero to more than four times the average annual volume.

\section{INTRODUCTION}

Inhabitants of the Tucson basin (fig. 1) are dependent entirely on ground water for their water supply. Since 1940, there has been 
a rapid increase in population and a parallel increase in the withdrawal of ground water. The increase in ground-water withdrawal has created problems concerning the most feasible methods of management of the components of the ground-water system in order to obtain the maximum benefit from the limited supply; the main problem is insufficient knowledge of the interrelations, magnitude, and natural behavior of the components of the groundwater system. The infiltration and percolation of flow to the ground-water reservoir from ephemeral streams is one component of the ground-water system that has not been adequately defined.

The study of infiltration of streamflow in the Tucson basin is a part of a comprehensive investigation undertaken by the U.S. Geological Survey in cooperation with the city of Tucson, the U.S.

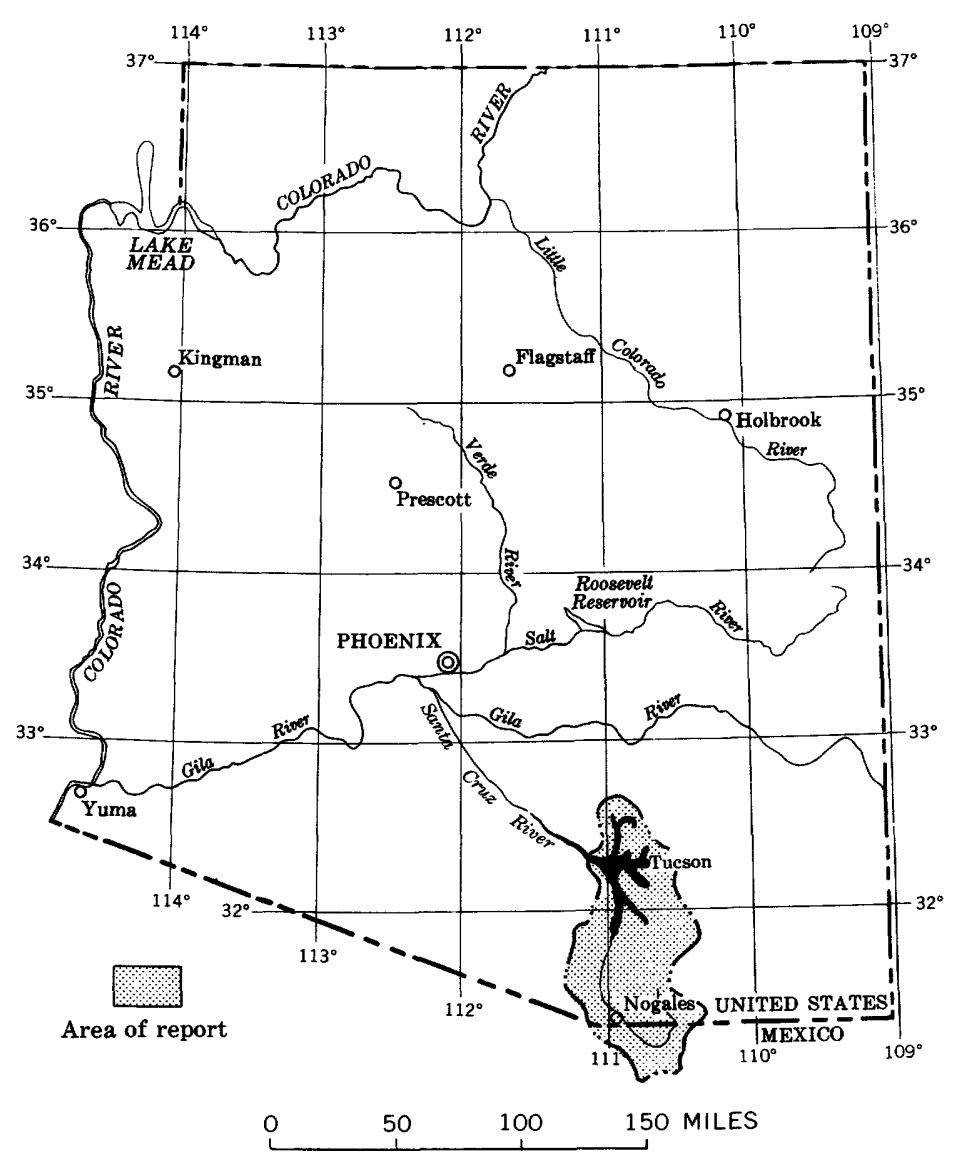

FIGURE 1.-Location of report area (stippled). 
Bureau of Reclamation, and the University of Arizona to appraise the water resources of the area. The work was done under the general supervision of $\mathrm{H}$. M. Babcock, district chief of the Water Resources Division in Arizona.

\section{PURPOSE AND SCOPE}

The purpose of this study was to compute the approximate average annual volume of infiltration from the unregulated surface flow in the normally dry main channels-Santa Cruz River, Tanque Verde Creek, Agua Caliente Wash, Sabino and Rincon Creeks, Pantano Wash, Rillito Creek, Big Wash, and Canada del Oro-in the Tucson basin. Available data for the period 1936-63 were used for the study. As determined in this report, the average annual infiltration is an estimate of the greatest possible average annual ground-water recharge occurring naturally along the main channels.

Determinations of average annual infiltration volumes were made for seven reaches of the main channels in the Tucson basin (pl. 1). In addition estimates of average annual infiltration volumes were made for the 10-mile reach of the Santa Cruz River from the southern boundary of Pima County to Continental and for the 5.5-mile reach of the Santa Cruz River from Cortaro to Rillito. The infiltration volumes were computed using streamflow data.

\section{METHOD OF ANALYSIS}

The method used to determine the average annual volume of infiltration in a reach of a main channel in the Tucson basin is summarized as follows: (1) Compute or estimate the average relation between inflow rate and infiltration rate for each source of inflow on the basis of streamflow data, (2) develop flow-duration curves for streamflow from each flow source, (3) apply infiltration rates obtained from inflow- to infiltration-rate relations to the appropriate flow-duration curve to derive infiltration-duration curves, (4) determine the average annual volume of infiltration from the infiltration-duration curve, and (5) use a budget of water volumes to confirm arithmetical agreement between synthesized and measured outflow. In determining the average annual volume of infiltration, the streamflow that enters a reach by the main channel and the streamflow from each tributary are treated individually.

\section{BASIC DATA}

Streamflow data from 16 gaging stations (pl. 1; table 1) in or near the Tucson basin were used to derive flow-duration curves 
and average inflow- to infiltration-rate relations for the seven reaches. In addition, several seepage measurements were available for sites other than regular gaging stations, and some of these measurements were used in estimating the average relation between infiltration and streamflow rates.

TABLE 1.-Streamflow-gaging stations in or near the Tucson basin

\begin{tabular}{|c|c|}
\hline $\begin{array}{l}\text { Station } \\
\text { (see fig. 10) }\end{array}$ & $\begin{array}{l}\text { Period of record } \\
\text { used in analysis }\end{array}$ \\
\hline 1 & Santa Cruz River near Lochiel \\
\hline 2 & Santa Cruz River near Nogales. \\
\hline 3 & Santa Cruz River at Continental.... \\
\hline & Do $\ldots \ldots \ldots \ldots \ldots \ldots$ \\
\hline 4 & Santa Cruz River at Tueson............... \\
\hline $\mathbf{5}$ & Tucson Arroyo at Vine Avenue, Tucson .......... \\
\hline 6 & Tanque Verde Creek near Tucson . . . . . . . . . . \\
\hline 7 & Sabino Creek near Tucson............... \\
\hline 8 & Bear Creek near Tucson............... \\
\hline 9 & $\begin{array}{l}\text { Tanque Verde Creek at Tucson (formerly called Rillito Creek. . . June 1940-Dec. } 1946 . \\
\text { near Wrightstown) }\end{array}$ \\
\hline 10 & Pantano Wash near Irene $\ldots \ldots \ldots \ldots \ldots \ldots \ldots \ldots \ldots \ldots \ldots \ldots$ July 1940-Dec. 1941. \\
\hline 11 & Pantano Wash near Vail. \\
\hline 12 & Rincon Creek near Tucson. . \\
\hline 13 & Pantano Wash near Tueson... \\
\hline 14 & 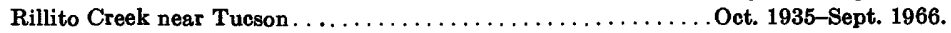 \\
\hline 15 & $\begin{array}{l}\text { Santa Cruz River at Cortaro (formerly called Santa Cruz River. Oct. 1939-May } 1947 . \\
\text { at Rillito) }\end{array}$ \\
\hline & 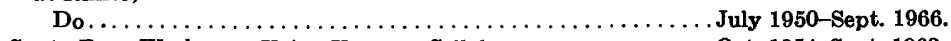 \\
\hline 16 & Santa Rosa Wash near Vaiva Vo, near Sells1 . . . . . . . . . . . . Oct. 1954-Sept. 1963. \\
\hline
\end{tabular}

1 Station not shown on plate 1.

Data used to describe the reaches were obtained from topographic maps or aerial photographs. Depth to the water table was measured in wells along the reaches. Sediment-size data for some of the reaches were used to describe the channel alluvium.

\section{CHARACTERISTICS OF THE STUDY AREA DESCRIPTION OF THE BASIN}

The Tucson basin, which is a northwest-sloping valley bordered by narrow rugged mountain ranges, comprises an area of about 1,000 square miles. The city of Tucson is centrally located within the basin. The part of the basin discussed in this report is about 40 miles long and ranges from about 4 to 20 miles wide. The mountains that border the basin range from 4,000 to 9,000 feet above mean sea level. The altitude of the land surface at the downstream end of the basin is 2,140 feet above mean sea level.

The climate of the Tucson basin is semiarid; the annual potential evaporation greatly exceeds the annual precipitation. The average annual precipitation at Tucson (alt 2,300 ft) is about 11 inches; however, on Mount Lemmon (alt about 9,200 ft), about 20 miles 
from Tucson, the annual precipitation is more than 30 inches. The average annual class $A$ pan evaporation at Tucson is about 90 inches.

In general the Tucson basin has a sparse cover of desert growth; cactus and mesquite are the most common vegetation types. The lower slopes of the mountains have a sparse cover of desert vegetation and chaparral, but above an altitude of about 6,000 feet there is a dense forest of coniferous trees, mainly pine.

The mountains that border the basin are composed of crystalline granitic rocks and relatively impervious sedimentary and volcanic rocks. The basin is underlain by unconsolidated and semiconsolidated alluvial material to depths of several thousand feet. The main channels of the basin are entrenched in stream alluvium of unconsolidated clay, silt, sand, and gravel. The stream alluvium is from 20 to more than 100 feet thick.

The main drainage for the basin is the north- to northwesttrending Santa Cruz River and its principal tributaries-Rillito Creek and Canada del Oro. Pantano Wash, its tributary Rincon Creek, and Tanque Verde Creek drain the southeastern part of the area and are tributary to Rillito Creek (pl. 1).

\section{DESCRIPTION OF THE MAIN CHANNELS}

The main channels in the Tucson basin are the Santa Cruz River, Tanque Verde Creek, Agua Caliente Wash, Sabino and Rincon Creeks, Pantano Wash, Rillito Creek, Big Wash, and Canada del Oro (pl. 1). Seven reaches of the main channels were used in this study. In downstream order, the reaches are (1) Santa Cruz River from the gaging station at Continental to the gaging station at Tucson, (2) Tanque Verde Creek from Sabino Canyon road 10.5 miles upstream to the gaging station in the foothills of the Santa Catalina Mountains, Sabino Creek from Tanque Verde Creek upstream 3 miles to its confluence with Bear Creek, and Agua Caliente Wash from Tanque Verde Creek upstream about 4 miles to its confluence with Soldiers Canyon, (3) Rincon Creek from the gaging station near Tucson to Pantano Wash, (4) Pantano Wash from the gaging station near Vail to Rillito Creek, (5) Tanque Verde Creek from Sabino Canyon road downstream to Pantano Wash and Rillito Creek from Pantano Wash to the gaging station on Rillito Creek near Tucson, (6) Canada del Oro from the foothills of the Santa Catalina Mountains to the Santa Cruz River and Big Wash from Canada del Oro upstream 12 miles, and (7) Santa Cruz River from the gaging station at Tucson to the gaging station at Cortaro and Rillito Creek from the gaging station near Tucson to the Santa Cruz River. The individual reaches are from 
7.8 to 28.5 miles long, and the total length of all the reaches is 137.5 miles (table 2).

TABLE 2.-Characteristics of the seven study reaches of the main channels, Tucson basin

\begin{tabular}{|c|c|c|c|c|c|c|c|}
\hline $\begin{array}{l}\text { Reach } \\
\text { (see pl. 1) }\end{array}$ & Stream & $\begin{array}{l}\text { Length } \\
\text { of } \\
\text { reach } \\
\text { (miles) }\end{array}$ & $\begin{array}{l}\text { Width } \\
\text { at } \\
\text { bankfull } \\
\text { stage } \\
\text { (ft) }\end{array}$ & $\begin{array}{l}\text { Depth } \\
\text { at } \\
\text { bankfull } \\
\text { stage } \\
\text { (ft) }\end{array}$ & $\begin{array}{l}\text { Size classification of } \\
\text { alluvium underlying } \\
\text { the channel }\end{array}$ & $\begin{array}{l}\text { Depth to } \\
\text { ground } \\
\text { water } \\
\text { below } \\
\text { channel } \\
\text { bed) }\end{array}$ & $\begin{array}{l}\text { Mean } \\
\text { slope } \\
(\mathrm{ft} / \mathrm{ft})\end{array}$ \\
\hline 1 & Santa Cruz River...... & 28.5 & $100-300$ & $5-30$ & Clay to pebble........ & $20-100$ & 0.003 \\
\hline 2 & $\begin{array}{l}\text { Tanque Verde Creek... } \\
\text { Sabino Creek. ...... } \\
\text { Agua Caliente Wash... } \\
\text { Total for reach } 2\end{array}$ & $\begin{array}{r}10.5 \\
3.0 \\
4.0 \\
17.5 \\
\end{array}$ & $\begin{array}{l}50-250 \\
50-250 \\
50-250\end{array}$ & $\begin{array}{l}5-15 \\
5-15 \\
5-15\end{array}$ & $\begin{array}{l}\text { Coarse sand to cobble.. } \\
\text { Coarse sand to cobble.. } \\
\text { Coarse sand to cobble.. }\end{array}$ & $\begin{array}{l}5-30 \\
5-10 \\
5-30\end{array}$ & $\begin{array}{l}.005 \\
\ldots \cdots \cdots \\
\cdots \cdots \cdots\end{array}$ \\
\hline 3 & Rincon Creek......... & 7.8 & $5-100$ & $1-5$ & Clay to cobble...... & $10-100$ & .006 \\
\hline 4 & Pantano Wash . ....... & $\overline{21.5}$ & $100-300$ & $10-30$ & Clay to boulder....... & $100-150$ & .007 \\
\hline \multirow[t]{2}{*}{5} & \multirow{2}{*}{$\begin{array}{r}\text { Tanque Verde Creek... } \\
\text { Rillito Creek........ } \\
\text { Total for reach } 5\end{array}$} & $\begin{array}{l}2.0 \\
7.5 \\
\end{array}$ & $\begin{array}{r}50-250 \\
100-500\end{array}$ & $\begin{array}{r}5-15 \\
10-20\end{array}$ & $\begin{array}{l}\text { Coarse sand to cobble.. } \\
\text { Clay to boulder....... }\end{array}$ & $\begin{array}{c}5-30 \\
30-100\end{array}$ & $\begin{array}{l}.004 \\
.004\end{array}$ \\
\hline & & 9.5 & $\cdots$ & . & жюn & $\cdots$ & $\cdots \cdots$ \\
\hline \multirow[t]{4}{*}{6} & \multirow{3}{*}{$\begin{array}{l}\text { Canada del Oro } \\
\text { Santa Catalina Moun- } \\
\text { tains to Big Wash. } \\
\text { Big Wash to Santa } \\
\text { Cruz River. } \\
\text { Big Wash.......... }\end{array}$} & -14.2 & $50-300$ & $5-15$ & Coarse sand to cobble.. & $5-100$ & .012 \\
\hline & & 9.9 & $50-300$ & $5-15$ & Silt to coarse gravel ... & $50-100$ & .008 \\
\hline & & 12.0 & $50-150$ & $5-10$ & $\begin{array}{l}\text { Silty sand to coarse } \\
\text { gravel. }\end{array}$ & $50-100$ & .012 \\
\hline & Total for reach 6 & 36.1 & & & & & ." \\
\hline \multirow[t]{3}{*}{7} & \multirow{2}{*}{$\begin{array}{r}\text { Santa Cruz River..... } \\
\text { Rillito Creek......... } \\
\text { Total for reach } 7\end{array}$} & $\begin{array}{r}12.3 \\
4.3\end{array}$ & $\begin{array}{l}100-500 \\
100-500\end{array}$ & $\begin{array}{l}10-20 \\
10-20\end{array}$ & $\begin{array}{l}\text { Clay to pebble......... } \\
\text { Clay to pebble....... }\end{array}$ & $\begin{array}{l}50-100 \\
50-100\end{array}$ & $\begin{array}{l}.003 \\
.003\end{array}$ \\
\hline & & 16.6 & $\cdots \cdots \cdots$ & $\cdots$ & ...... & $\cdots$ & $\cdots$ \\
\hline & $\begin{array}{l}\text { Total for main } \\
\text { channels. }\end{array}$ & $\overline{137.5}$ & & & & & \\
\hline
\end{tabular}

Except for the reach of Rincon Creek, the channels are continuous, are entrenched in stream alluvium to depths of 5-30 feet, and are 50-500 feet wide at bankfull stage (table 2). The channels are therefore, in most places, sufficiently large to contain most floodflows. Near the upstream end of reach 3, Rincon Creek is 3-5 feet deep and 30-100 feet wide at bankfull stage; here the channel contains most floodflows. Farther downstream near Pantano Wash, however, Rincon Creek has no definite channel, and flows of any magnitude spread out across the flood plain.

The stream alluvium that underlies the main channels ranges in size from clay to boulder (table 2). During periods of no flow, the alluvium along the channel beds normally is stratified-clay and silt on the surface and clay, silt, and sand interbedded with gravel below the surface-except perhaps in reaches 2 and 5 upstream from Pantano Wash. Only small amounts of clay and silt are present in the alluvium along reach 2 and along reach 5 upstream from Pantano Wash; therefore, any clay deposited on 
the channel beds of these reaches during periods of no flow would be thin. The average sediment size of the alluvium underlying reaches $1,4,5$, and 7 apparently increases with depth, as indicated by samples taken along the reaches (figs. 2, 3, and 4). The stream alluvium underlying the seven reaches is from 30 to more than 100 feet thick except near the mountains in reaches 2,3 , and 6 , where, in places, the stream alluvium is less than 10 feet thick.

The mean slopes of the main channels range from 0.003 foot per foot in reaches 1 and 7 to 0.012 foot per foot in reach 6 (table 2). The mean slope for a reach is the difference in altitude of the channel bed at the inflow and outflow points divided by the length of the intervening reach measured along the channel.

\section{DEPTH TO GROUND WATER ALONG THE MAIN GHANNELS}

The depth to ground water along the main channels is from 20 to 150 feet below the channel beds except near the mountains (table 2); near the mountains the depth to water is less than 20 feet even after dry periods in places in reaches $2,3,5$, and 6. Occasionally the water table intercepts the streambed during flows of long duration.

\section{STREAMFLOW}

The main channels of the Tucson basin normally are dry, and flow occurs only in response to direct precipitation. In the foothills a few small springs flow almost perennially, but the water is lost quickly in the stream alluvium as the flow moves away from the foothills. Near the mountains, where ground water normally is found at relatively shallow depths, the water table occasionally intercepts the streambed in a few places during prolonged periods of surface flow. Flow from this source may continue for long periods after upstream surface flow has ceased. For example, occasionally there is flow in Tanque Verde Creek downstream from Sabino Creek after upstream surface flow has ceased; however, the flow from this source quickly infiltrates into the stream alluvium as the water moves downstream.

Streamflow in the main channels is mainly the result of two types of storms-thunderstorms and frontal storms. Generally, thunderstorms are predominant from July through October, and frontal storms are predominant from November through June. Rates of streamflow resulting from thunderstorms generally vary greatly in short periods of time, and the duration of flow usually is no more than 1 or 2 days. Streamflow resulting from precipitation produced by frontal storms may last for several days. Flow from July through October generally has a higher concentration of 


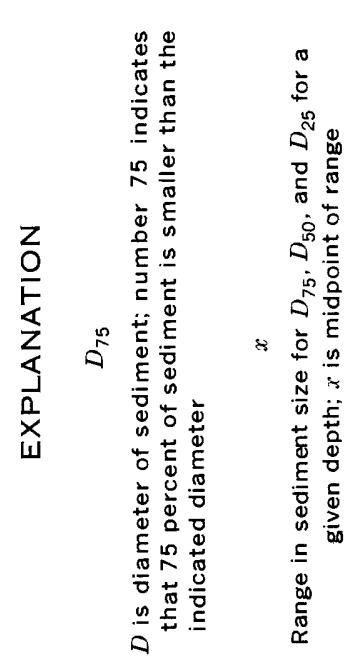

$\$$

ن

总

$\sum^{2}$

突

हึ

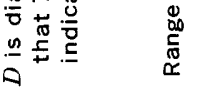

†
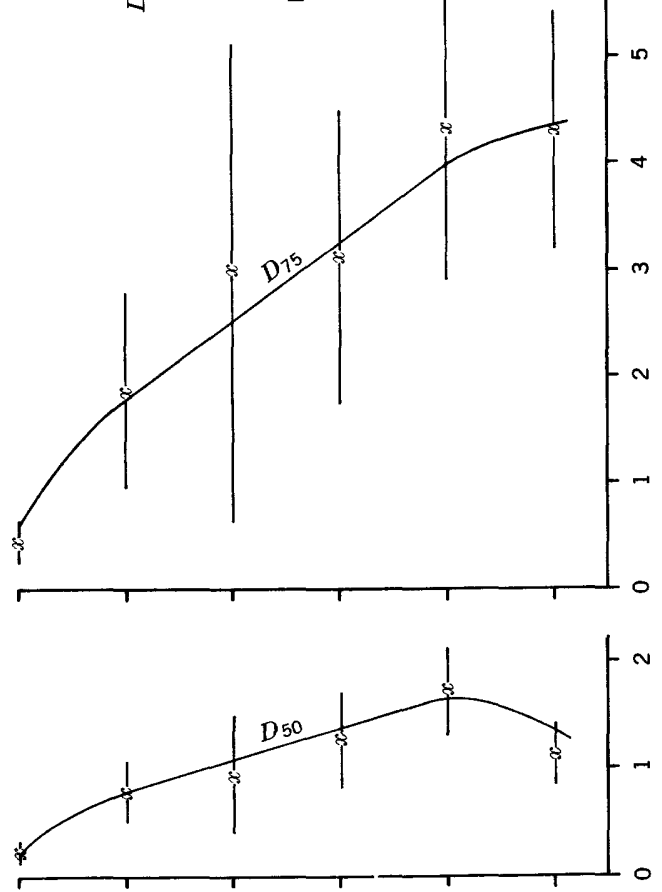

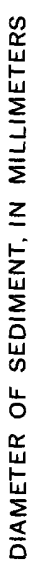

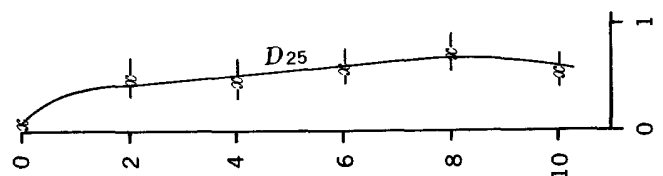

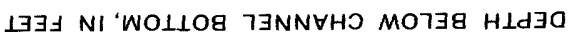

.ำ

$\vec{c}$

苛

\$્⿷

 


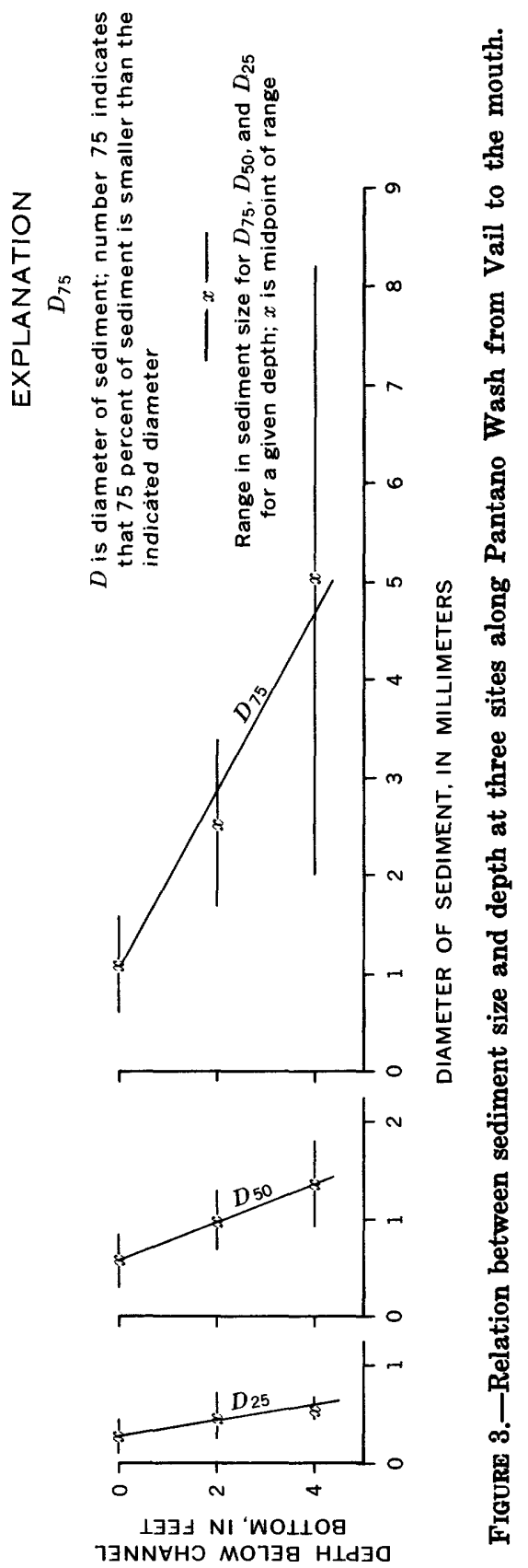




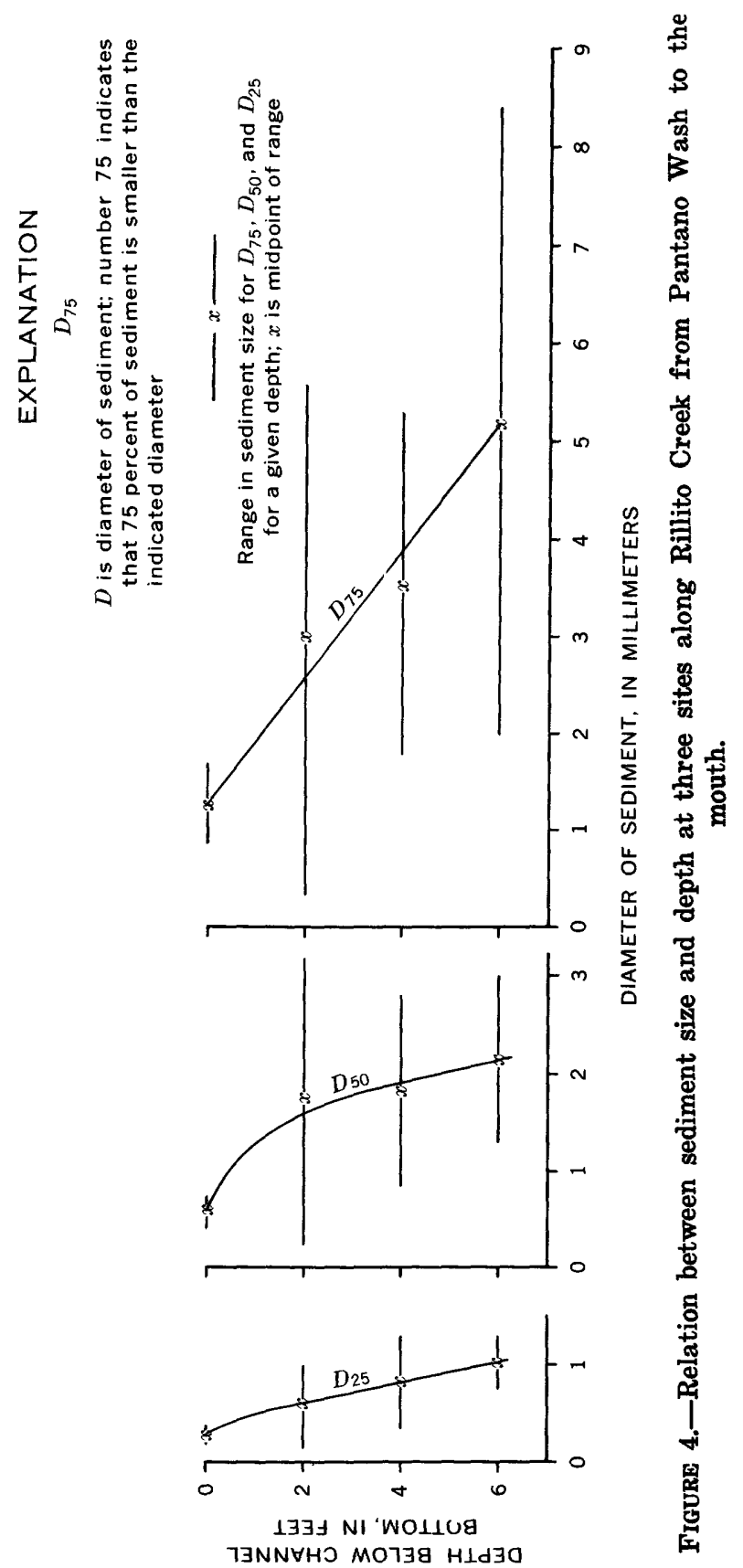


silt and clay than the flow during the rest of the year, probably because of differences in the intensity of precipitation and in areas of runoff.

The amount of flow from July through October relative to the amount from November through June is different for each of the seven reaches. About 85 percent of the outflow from the basin occurs from July through October; the same percentage of inflow to the main channels probably occurs during this period.

\section{INFILTRATION OF STREAMFLOW}

Infiltration, percolation, and recharge along the main channels of the Tucson basin are closely related. Infiltration is the flow of a fluid into a substance through pores or small openings, and percolation is the movement of water within the porous media. Recharge is that part of infiltrated water that eventually reaches the ground-water reservoir. Infiltrated water is depleted as it percolates through the unsaturated zone and brings the zone to field capacity (the condition at which gravity flow ceases); therefore, the average annual recharge to the ground-water reservoir is less than the average annual infiltration along a stream. The part of the average annual infiltrated water that reaches the ground-water reservoir is not known but probably is more than 90 percent. The amount of moisture necessary to bring the unsaturated zone to field capacity is a direct result of the amount of evapotranspiration that occurs between surface-flow events.

During a stormflow event in a main channel, the volume of runoff is increased by tributary inflow and precipitation on the flowing water and is depleted by evaporation and infiltration. Because the net difference between evaporation from and precipitation on the flowing water is assumed to be negligible, the depletion of streamflow is assumed to be entirely through infiltration. In this report the rate (volume per unit time) and volume of streamflow depletion are assumed to be equal to the rate and volume of infiltration, and the terms "infiltration rate" and "streamflow-depletion rate" are used interchangeably.

Basically, the average annual volume of infiltration along the main channels was computed by multiplying approximate rates of infiltration by approximate duration of the rates. The rates of infiltration were derived from average stream inflow- to infiltration-rate relations. Frequencies of occurrence and duration of the infiltration rates were obtained from duration curves of inflow.

INFLOW. TO INFILTRATION-RATE RELATIONS

The average inflow- to infiltration-rate relations for the main 
channels were derived by using measured inflow and outflow rates or by estimating the coefficient in the empirical equation

in which

$$
Q_{f}=C\left(Q_{\text {inflow }}\right)^{0.8} \text {, }
$$

$Q_{f} \quad=$ infiltration rate, which is the difference between the surface-water inflow and outflow rates during corresponding time intervals in a reach, in cubic feet per second, ${ }^{1}$

$C \quad=$ a variable coefficient, and

$Q_{\text {inflow }}=$ surface-water inflow rate, in cubic feet per second. In the empirical equation, $C$ is a combined variable-that is, the effects of many variable parameters are combined (Burkham, 1970). In this report an average coefficient was determined or estimated for all flow moving through a given length of channel.

The inflow and outflow data used to determine the inflow- to infiltration-rate relation for a reach were for periods when there was no known tributary inflow. Average inflow and infiltration rates were computed from short-duration storms by dividing the inflow volume and the inflow volume minus the outflow volume, respectively, by the duration of inflow. The duration of inflow was the total time the inflow rate was 10 cfs (cubic feet per second) or greater. For fairly constant long-duration flows, instantaneous infiltration rates were computed as the difference between instantaneous rates of inflow and outflow. The instantaneous outflow rates were determined by correcting the time of occurrence of a particular inflow rate by the estimated time required to translate flowing water through the reach.

For reaches 1,5 , and 7 , the average inflow- to infiltration-rate relations were derived from flow measurements made at the end points. The data points for each reach were plotted on logarithmic coordinate paper, and the line of best fit was obtained by the method of least squares.

For reaches $2,3,4$, and 6 , the average inflow- to infiltration-rate relations were derived by estimating the coefficient $C$ in the equation $Q_{f}=C\left(Q_{\text {inflow }}\right)^{0.8}$. The estimated values of $C$ were based on scanty flow data or on a comparison between the hydraulic characteristics of the channels of reaches $2,3,4$, and 6 and reaches 1,5 , and 7 , for which the values of $C$ were defined as explained in the preceding paragraph.

\footnotetext{
1 The equation is used in estimating the infiltration rate only when the inflow rate $\left(Q_{\text {inflow }}\right)$ is greater than the computed infiltration rate $\left(Q_{f}\right)$. If the equation gives an infiltration rate greater than the inflow rate, the equation is not valid because the infiltration cannot be greater than the inflow.
} 


\section{REAGH 1}

Reach 1 is 28.5 miles long (pl. 1); many small tributaries, which drain a composite area of 560 square miles, contribute surface flow to the reach. In the inflow- to infiltration-rate computations, the infiltration from water that enters the reach through the main channel and the infiltration from water that enters the reach from the nine tributary basins were computed separately.

Figure 5 shows the graph of the inflow rates in the Santa Cruz River at Continental and the infiltration rates from Continental
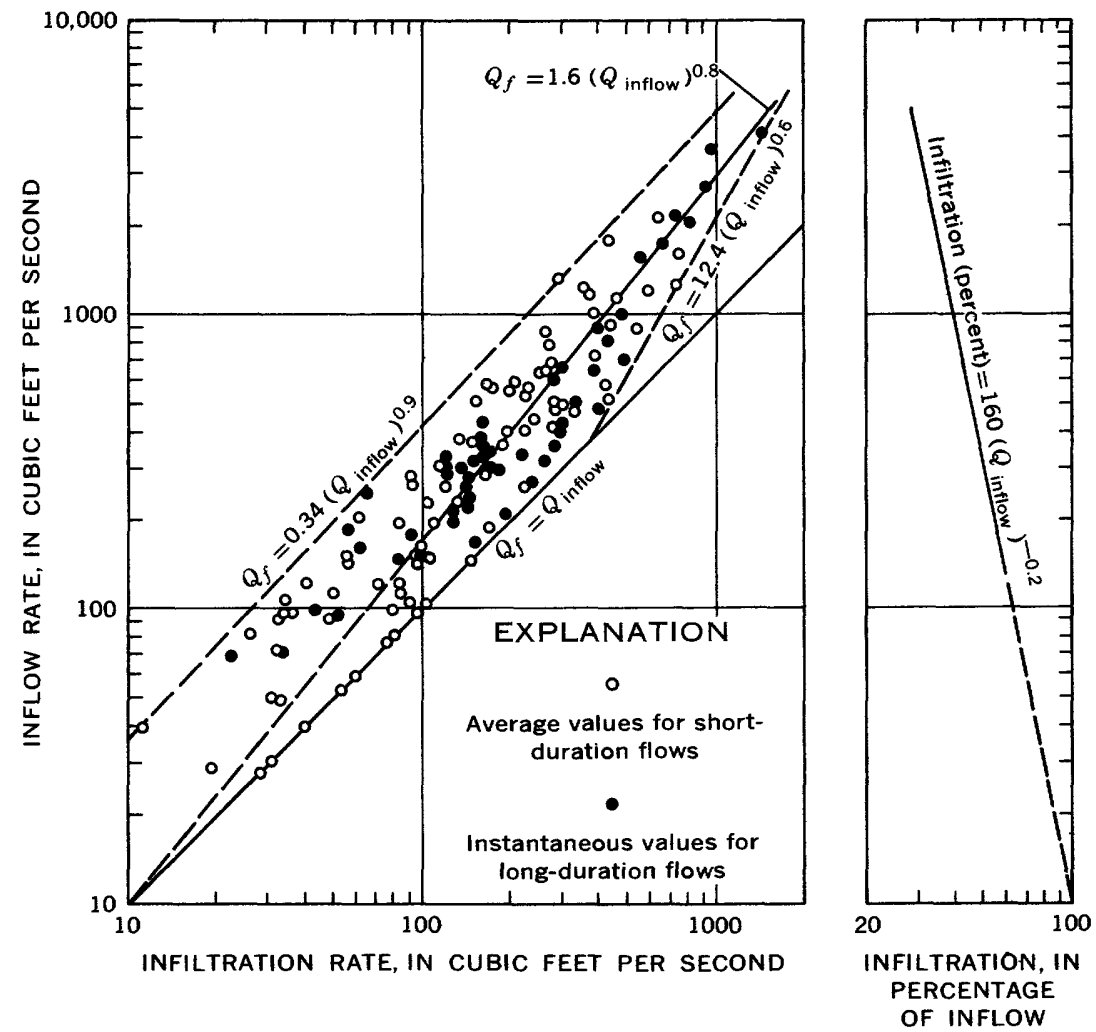

Figure 5.-Relation between inflow rates and infiltration rates for the 28.5mile reach 1, Santa Cruz River from Continental to Tucson, Ariz.

to Tucson. For this reach, 143 sets of inflow- and infiltration-rate data were available- 82 sets for short-duration flows and 61 sets for instantaneous rates for fairly constant long-duration flow. The equation for the line of best fit through the data is

$$
Q_{f}=1.6\left(Q_{\text {inflow }}\right)^{0.8} \text {. }
$$


From the above

$$
Q_{f} / \text { mile }=0.06\left(Q_{\text {inflow }}\right)^{0.8}
$$

would give the average per mile infiltration for reach 1 . This form of the equation was used to compute the infiltration of flow from tributary basins by multiplying by the length of subreach. The length of subreach is the distance between the tributary inflow point and the outflow point along the main channel.

The determination of infiltration rates by use of the per mile form of the preceding equation introduces a bias into the estimates of infiltration. Infiltration rates are not linearly related to length of channel as indicated by the per mile form of the equation. The bias probably would cause the estimates of average annual infiltration to be slightly smaller than actual infiltration.

During some flow events for which the average inflow rate was as much as $150 \mathrm{cfs}$, the total flow was depleted in transit through the reach. For these events, the length of channel in which water infiltrated was unknown. For reach 1 , the maximum average inflow that produced no outflow seems to have been $150 \mathrm{cfs}$; therefore, only the sets of data corresponding to an inflow rate of $150 \mathrm{cfs}$ or greater were used in the best-fit computation. The line of best fit was projected downward to include lower flows (fig. 5). The line $Q_{f}=Q_{\text {inflow }}$ for inflows of from 0 to $300 \mathrm{cfs}$ and the line $Q_{f}=12.4\left(Q_{\text {inflow }}\right)^{0.6}$ for inflows greater than 300 cfs probably represent the maximum infiltration rates that can be expected, without modification of the channel, for a given rate of inflow. The line $Q_{f}=0.34\left(Q_{\text {inflow }}\right)^{0.9}$ probably represents the minimum infiltration that may be expected for a given rate of unregulated inflow.

\section{REACH 5}

Rillito Creek is formed by Tanque Verde Creek and Pantano Wash. Reach 5, which is 9.5 miles long, encompasses parts of Tanque Verde and Rillito Creeks (pl. 1).

The average inflow rates and infiltration rates for 16 measured short-duration flow events are plotted on the graph in figure 6 . The maximum average inflow that produces no outflow is unknown; therefore, the data for all flow events were used in the bestfit computation. The equation for the line of best fit through the data is

or, for average per mile infiltration,

$$
Q_{f}=1.7\left(Q_{\text {inflow }}\right)^{0.8},
$$

$$
Q_{f} / \text { mile }=0.18\left(Q_{\text {inflow }}\right)^{0.8},
$$

which may be used to determine the infiltration rates from tributary inflow. 

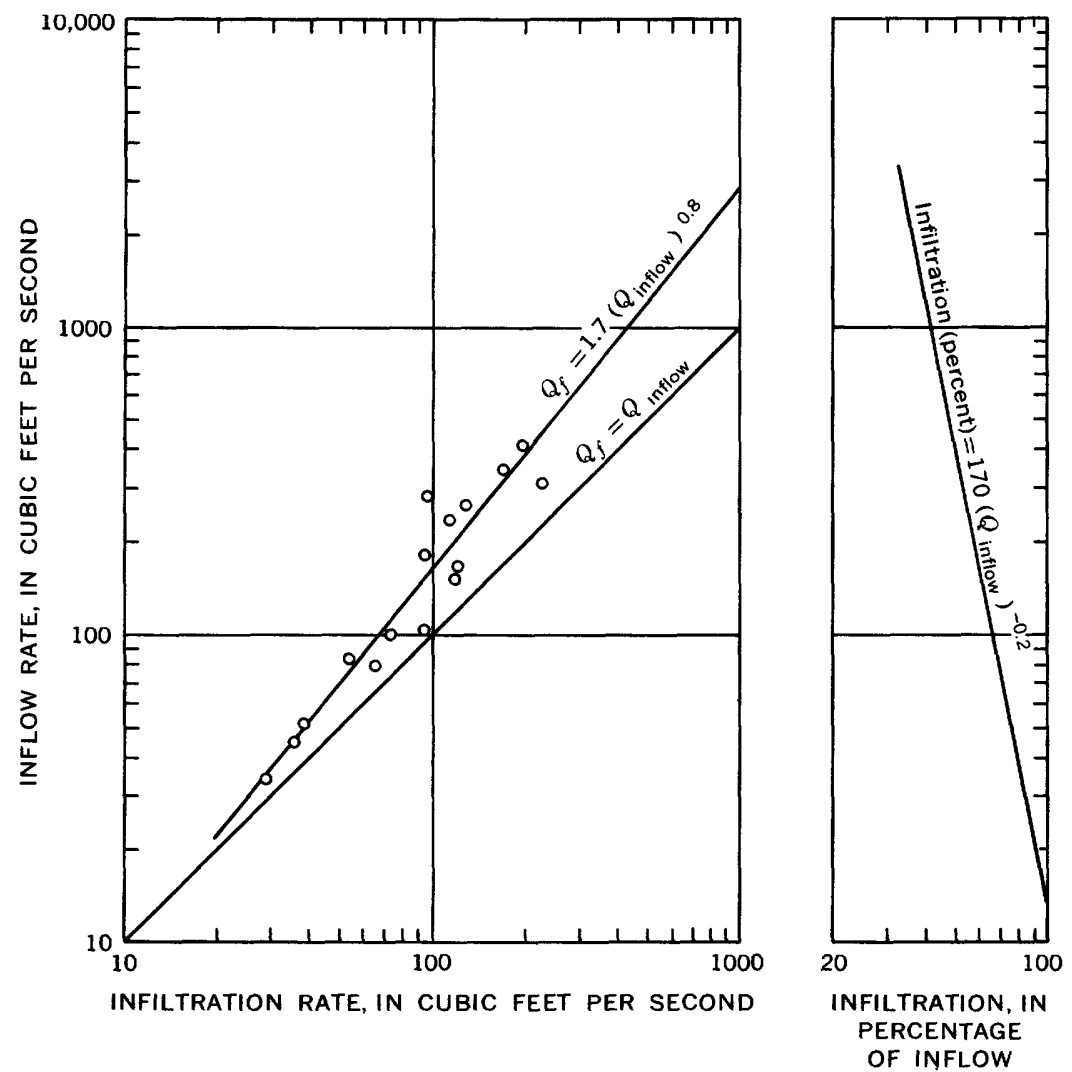

FIGURE 6.-Relation between inflow rates and infiltration rates for the 9.5-mile reach 5, Tanque Verde Creek at Sabino Canyon road to Rillito Creek near Tucson gaging station.

\section{REACH 7}

The channels of reach 7 include 12.25 miles of the Santa Cruz River and 4.3 miles of Rillito Creek (pl. 1). Figure 7 shows the graph of the inflow rates in the Santa Cruz River at Tucson and the infiltration rates in the 12.25-mile reach of channel to Cortaro for 41 flow events. The equation for the line of best fit through the data is

$$
Q_{f}=1.4\left(Q_{\text {inflow }}\right)^{0.8}
$$

or, for average per mile infiltration,

$$
Q_{f} / \text { mile }=0.11\left(Q_{\text {inflow }}\right)^{0.8},
$$

which may be used to determine the infiltration rates from tributary inflow by applying the appropriate length of channel, in miles. In the computations of infiltration volume, flow in the 4.3- 
mile reach along Rillito Creek and its tributaries was treated as tributary inflow.
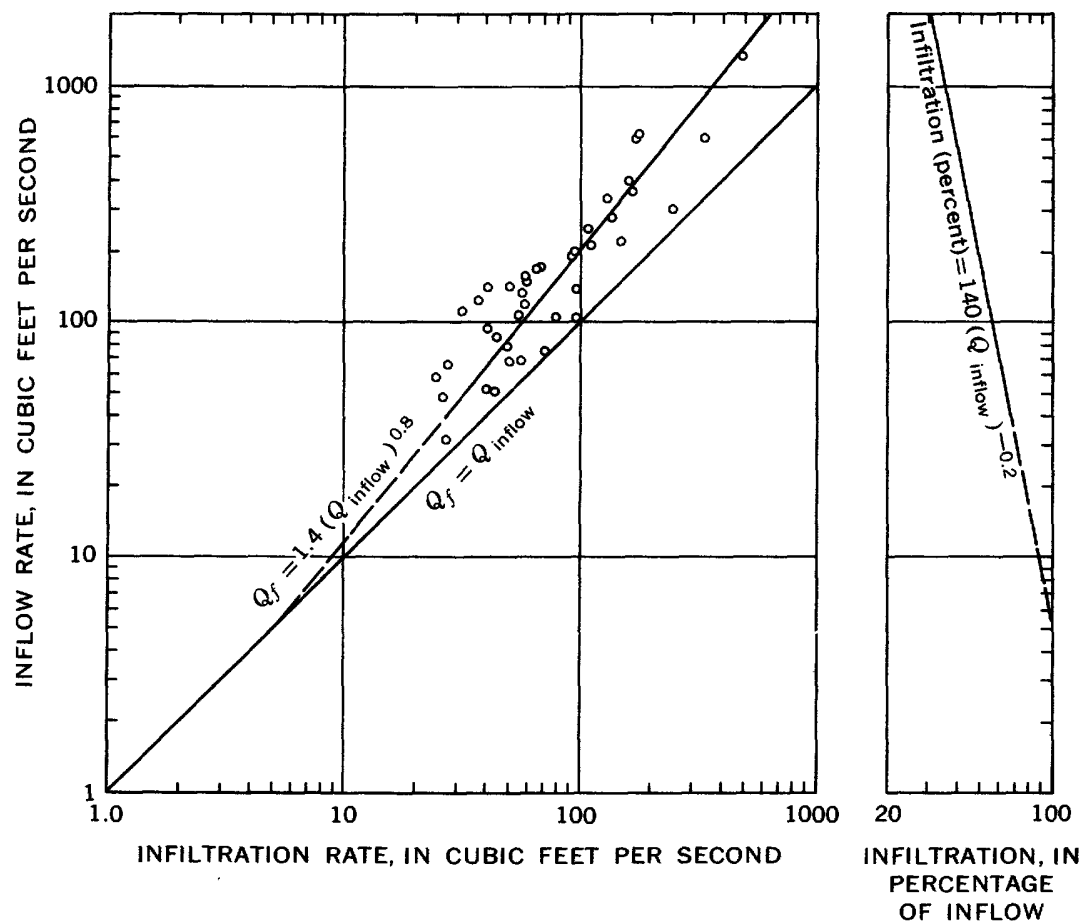

FIGURE 7.-Relation between inflow rates and infiltration rates for the 12.25-mile reach 7, Santa Cruz River at Tucson to Santa Cruz River at Cortaro, Ariz.

\section{REAGH 2}

Reach 2 includes a 10.5-mile reach of Tanque Verde Creek from the gaging station in the foothills of the Santa Catalina Mountains to Sabino Canyon road, a 3-mile reach of Sabino Creek from its confluence with Bear Creek to Tanque Verde Creek, and a 4-mile reach of Agua Caliente Wash from its confluence with Soldiers Canyon to Tanque Verde Creek (pl. 1) - a total length of $\mathbf{1 7 . 5}$ miles. The infiltration rate for short-duration flows probably is high in reach 2 because the channel bed is composed of coarse highly permeable material. During long-duration flows, infiltration rates probably are high initially, but the rates decrease with time because of interconnection between surface water and ground water and because of a reduction in length of unsaturated allu- 
vium. Figure 8 shows the inflow- to infiltration-rate relations for the two conditions.

Data from flow events for reach 2 were insufficient to define the average inflow- to infiltration-rate relation directly; however, the average per mile infiltration for a given inflow rate in reach 2 probably is about the same as that for reach 5. Infiltration rates in the main reach and the subreaches of reach 2 were computed from the per mile form of the equation for reach 5

$$
Q_{f}=0.18 L\left(Q_{\text {inflow }}\right)^{0.8},
$$

in which $L$ is the length of reach, in miles, in which infiltration took place for a given inflow rate.

\section{REACH 3}

The channel of reach 3 is 7.8 miles long. Seepage measurements made in 1965 and 1966 during long-duration flows indicate relatively low rates of infiltration in the 4.8-mile subreach from the gaging station to Camino Loma Alta and extremely high rates of infiltration in the 3.0-mile subreach from Camino Loma Alta to the Old Spanish Trail (fig. 9). The low rates of infiltration in the subreach from the gaging station to Camino Loma Alta probably are due to the small thickness of permeable alluvium and interference from shallow water. The high infiltration rates in the subreach from Camino Loma Alta to Old Spanish Trail result in part from the water spreading out over the flood plain.

The equation for the average inflow- to infiltration-rate relation for reach 3 is

$$
Q_{f}=2.5\left(Q_{\text {inflow }}\right)^{0.8}
$$

or, for average per mile infiltration,

$$
Q_{f} / \text { mile }=0.32\left(Q_{\text {inflow }}\right)^{0.8} \text {. }
$$

The equation was estimated from the data for seepage measurements and from knowledge of the hydraulic geometry of the reach.

REACH 4

The channel of reach 4 is 21.5 miles long. Data for inflow and infiltration rates were available for four flow events in Pantano Wash from Irene to its confluence with Rillito Creek and for 15 flow events that passed between the Pantano Wash near Vail and Rillito Creek near Tucson gaging stations. The equation for the average inflow- to infiltration-rate relation for reach 4 is

$$
Q_{f}=2.4\left(Q_{\text {inflow }}\right)^{0.8}
$$

or, for average per mile infiltration,

$$
Q_{f} / \text { mile }=0.11\left(Q_{\text {inflow }}\right)^{0.8} \text {. }
$$




\section{REACH 6}

Reach 6 consists of 24.1 miles of Canada del Oro from the foothills of the Santa Catalina Mountains to the Santa Cruz River and a 12.0-mile subreach-Big Wash from the foothills to its confluence with Canada del Oro. The total length of reach 6 is 36.1 miles.

Streamflow measurements in Canada del Oro are insufficient to establish an average inflow- to infiltration-rate relation. However, the bed material and the channel geometry of Canada del Oro

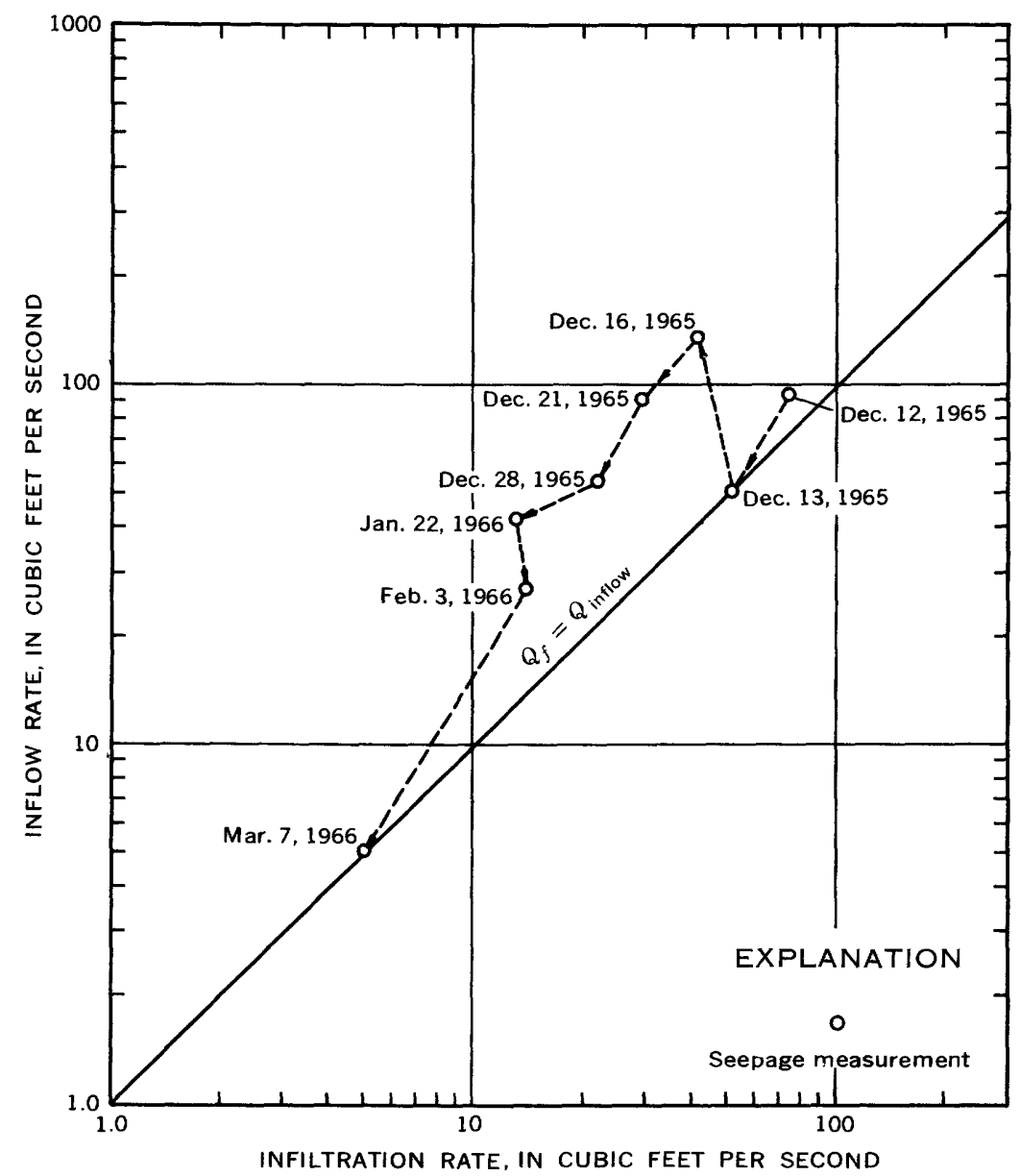

$A$

Figure 8.-Relation between inflow rates and infiltration rates for $(A)$ the Soldiers Canyon and for $(B)$ the 4.2-mile reach of Tanque Verde 
upstream from the mouth of Big Wash are similar to those of reach 5. Therefore, the equation

$$
Q_{f} / \text { mile }=0.18\left(Q_{\text {inflow }}\right)^{0.8},
$$

which was developed as the average per mile infiltration rate for reach 5, was used for making estimates of infiltration during flow events in Canada del Oro. The bed material and channel geometry of Big Wash and Canada del Oro downstream from Big Wash are similar to those of reach 1 ; therefore, the equation

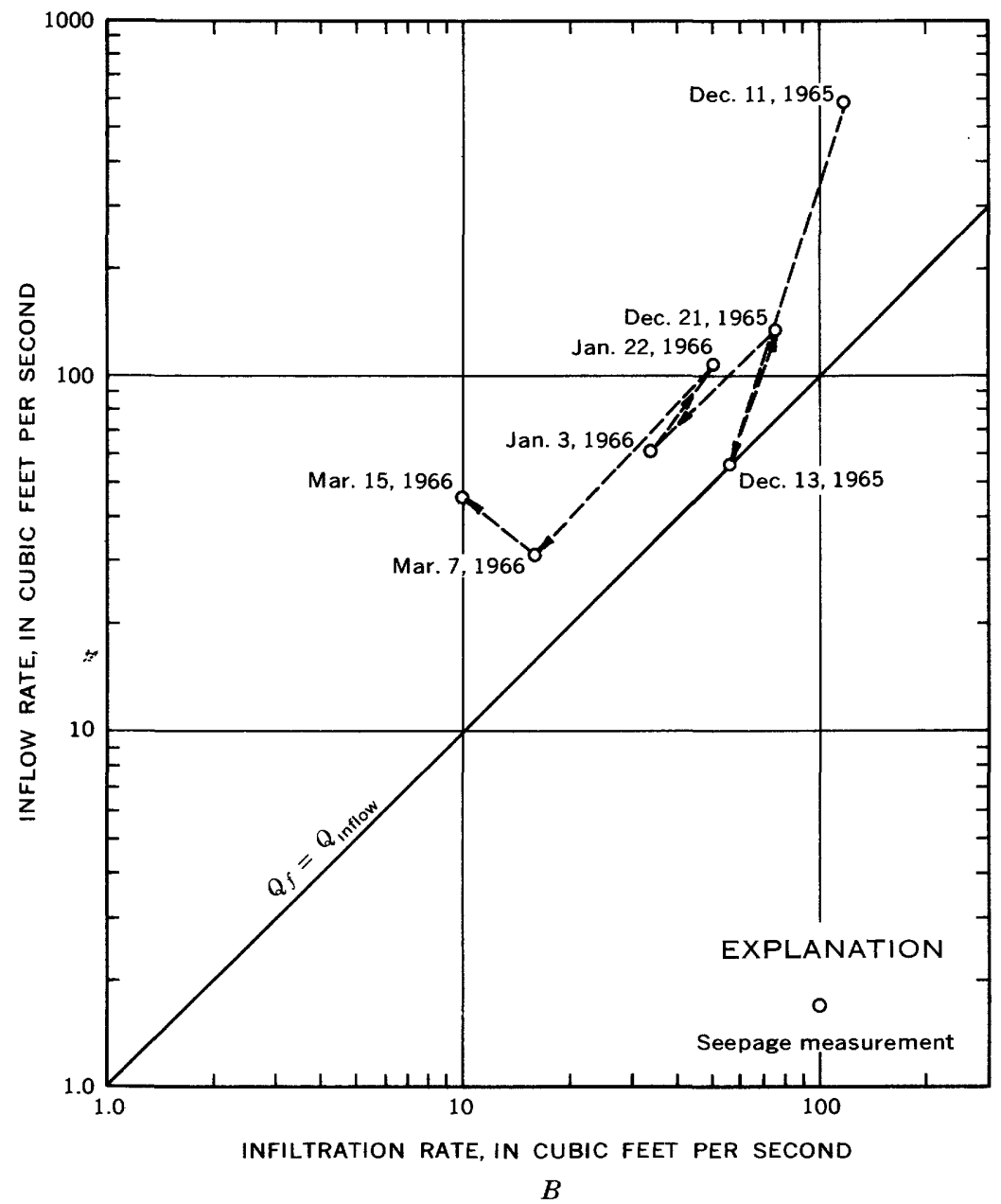

3.2-mile reach of Agua Caliente Wash from Tanque Verde road crossing to Creek from Tanque Verde Loop road to Tanque Verde road. 


$$
Q_{f} / \mathrm{mile}=0.06\left(Q_{\text {inflow }}\right)^{0.8},
$$

which was developed as the average per mile infiltration rate for reach 1, was used for making estimates of infiltration from streamflow in Big Wash and Canada del Oro below Big Wash.

\section{FLOW-DURATION CURVES}

Flow-duration curves for measured flows in the study area for the base period 1936-63 were developed by Condes (written commun., 1968). Synthetic flow-duration curves for ungaged tributary streams were derived from simple relations and size of contributing basin for flow that is equaled or exceeded $0.1,0.5,2.0$, and 10 percent of the time (fig. 10). In defining the relations, gagingstation data from 10 streams were used. Some of these streams flow in the winter, whereas most of the ungaged tributaries in the study area flow in the summer. Therefore, in defining the basin-discharge relation, only the data for summer daily flows

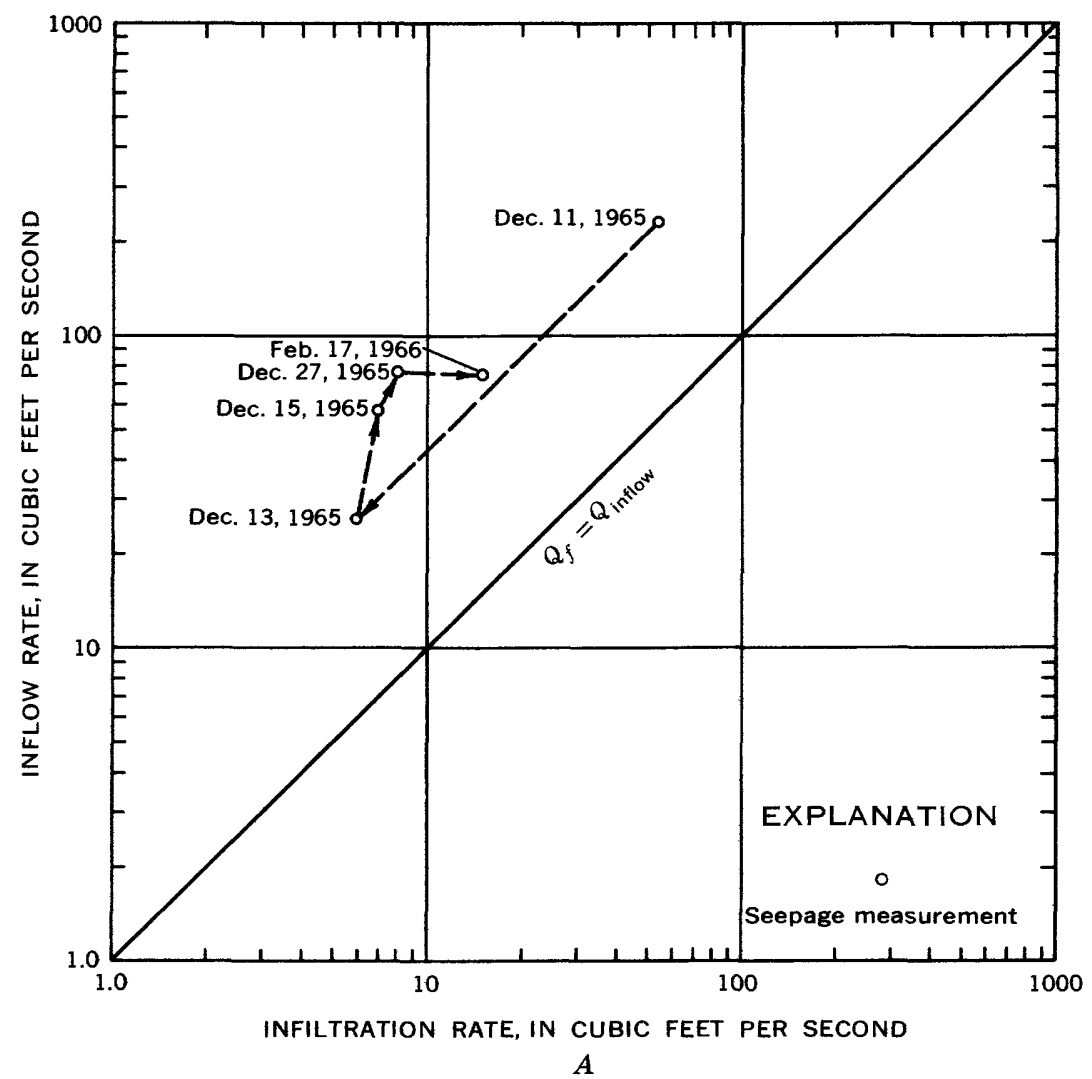

FIGURE 9.-Relation between inflow rates and infiltration rates for $(A)$ the station to Camino Loma Alta and for $(B)$ the 3.0-mile reach of 
were used, and frequencies were computed using summer flow as the total flow for the year. These drainage basins are mostly below an altitude of 6,000 feet. In defining the lines more emphasis was given to data for drainage basins that are hydrologically and physiographically similar to the basins that are tributary to the study reaches than to data for basins that are not similar. Points 1, 7, and 12 (fig. 10 and table 1) represent drainage basins that are mostly mountainous, and, therefore, are not similar to the tributary basins. Of the four lines shown in figure 10, the lines representing flows that are equaled or exceeded 0.1 and 0.5 percent of the time are most nearly defined; the 2.0 percent line, which was drawn parallel to them, is fairly well defined. The flow equaled or exceeded 10 percent of the time was greater than zero at only 5 of the 10 stations; for that reason the 10 percent line was drawn parallel to the 0.1 and 0.5 percent lines.

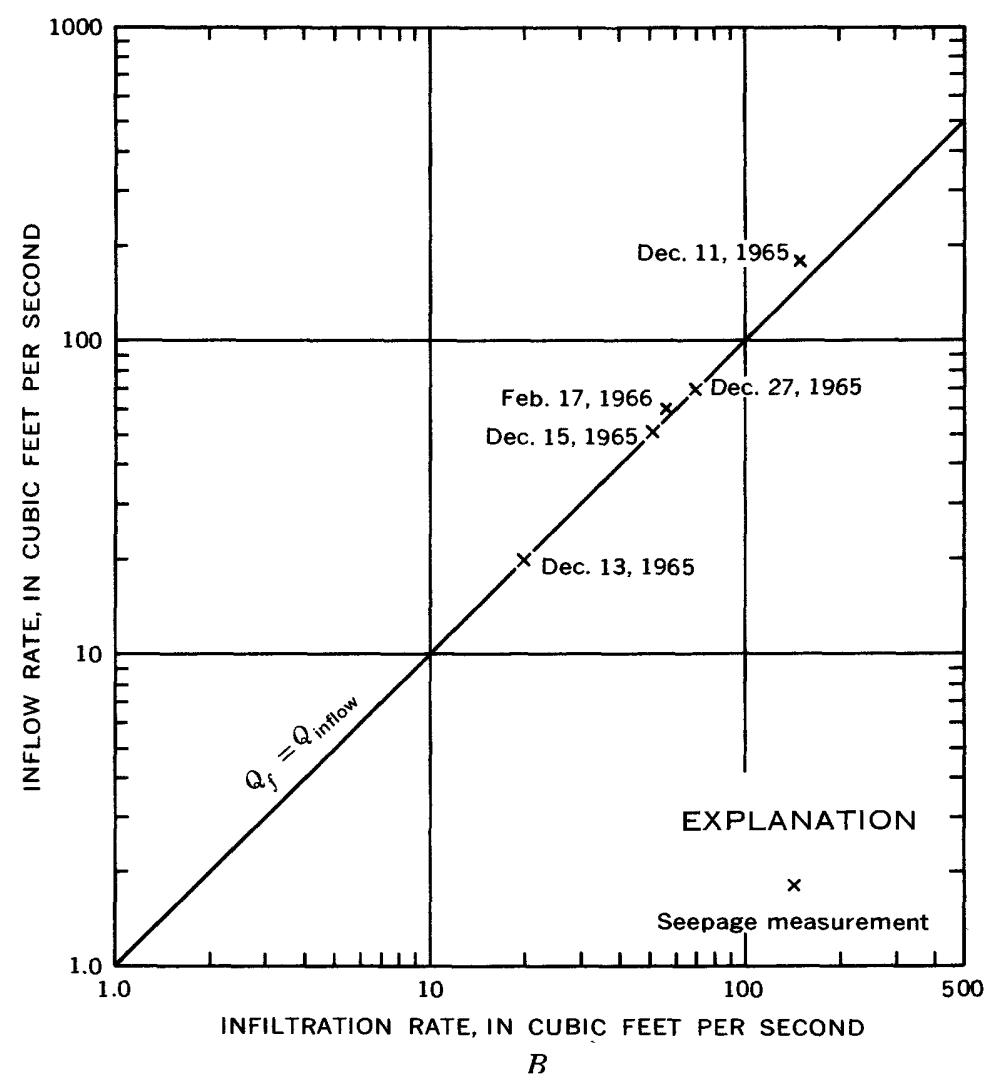

4.8-mile reach of Rincon Creek from the Rincon Creek near Tucson gaging Rincon Creek from Camino Loma Alta to Old Spanish Trail. 


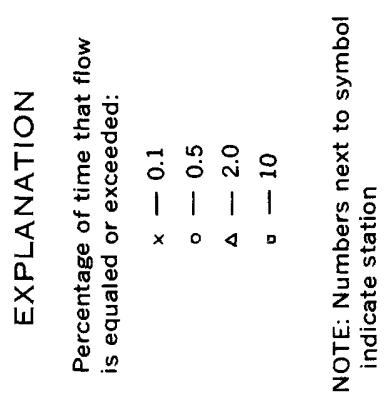

8
8
0
4
0
0
0
0
0
0
0
0
0
0
0

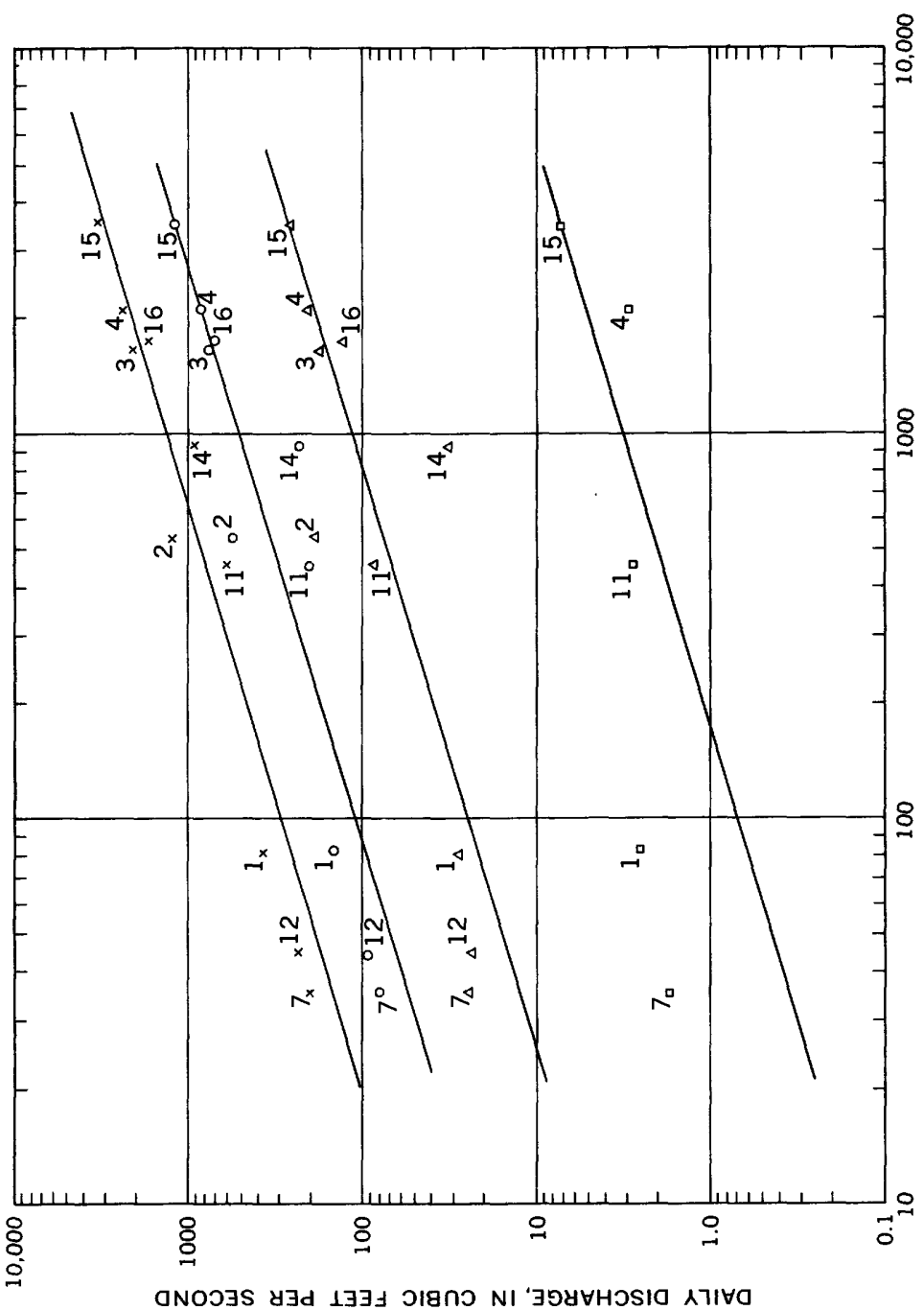

돔

8 
From figure 10, for a tributary drainage area of 106 square miles (tributary 1-4, pl. 1) the flow would equal or exceed $320 \mathrm{cfs}$

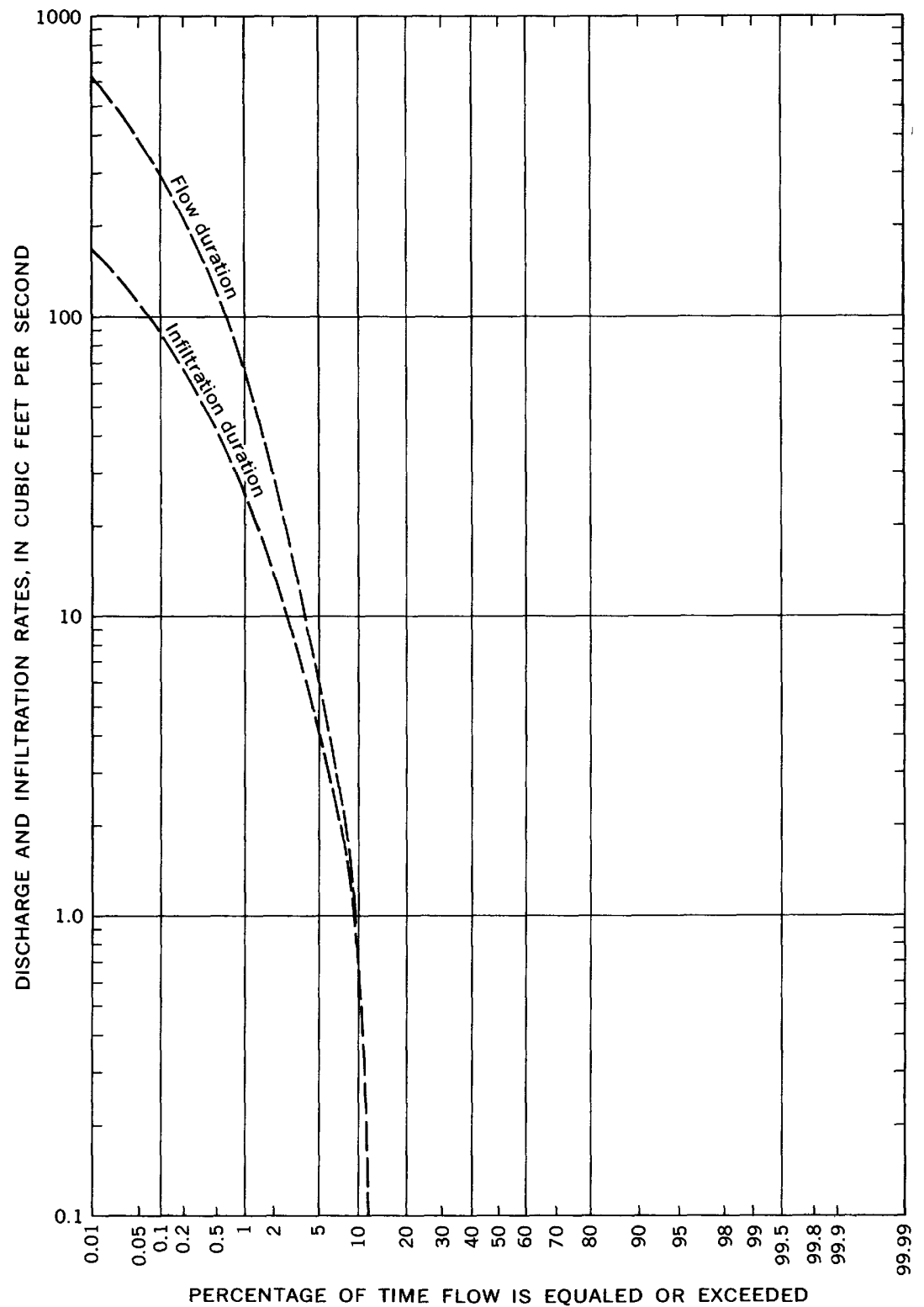

FIgURE 11.-Flow duration for tributary 1-4 and infiltration duration as water moves down the Santa Cruz River from mouth of 1-4 to Santa Cruz River at Tucson, Ariz. 
TABLE 3.-Water budget of average annual measured or synthesized seven reaches of the main

\begin{tabular}{|c|c|c|c|}
\hline \multirow[b]{2}{*}{ Inflow point (see pl. 1) } & \multicolumn{2}{|c|}{ Drainage area } & \\
\hline & $\mathrm{Sq} \mathbf{m i}$ & $\begin{array}{l}\text { Percent- } \\
\text { age of } \\
\text { total }\end{array}$ & $\begin{array}{l}\text { pont of of } \\
\text { inflow } \\
\text { to end } \\
\text { of reach, } \\
\text { in miles }\end{array}$ \\
\hline
\end{tabular}

Reach 1. Santa Cruz River

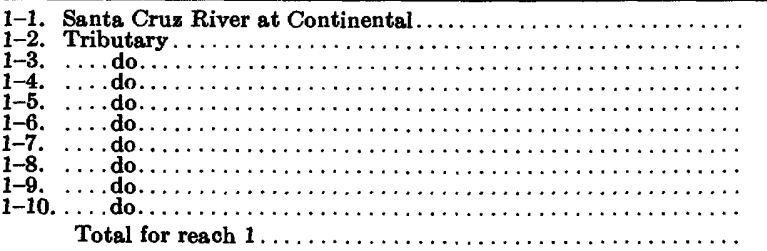

\begin{tabular}{rrr}
$1,662.0$ & 74.8 & 28.5 \\
91.8 & 4.1 & 23.2 \\
57.4 & 2.6 & 23.0 \\
105.8 & 4.8 & 17.0 \\
65.7 & 2.9 & 14.2 \\
100.8 & 4.5 & 10.2 \\
37.7 & 1.7 & 8.2 \\
34.5 & 1.6 & 3.5 \\
20.2 & .9 & 3.2 \\
48.1 & 2.1 & .8 \\
\hline $2,224.0$ & 100.0 & $\ldots \ldots \ldots$
\end{tabular}

Reach 2. Tanque Verde Creek and tributaries from foothills

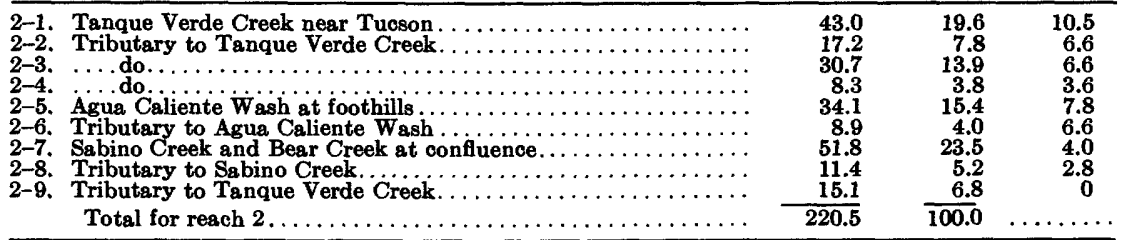

Reach 3. Rincon Creek from gaging

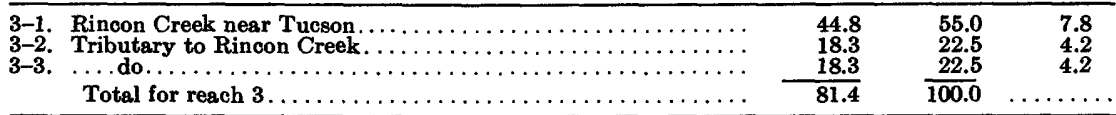

Reach 4. Pantano Wash from gaging

\begin{tabular}{|c|c|c|c|c|}
\hline $\begin{array}{l}4-1 . \\
4-2 . \\
4-3 . \\
4-4 . \\
4-5 .\end{array}$ & 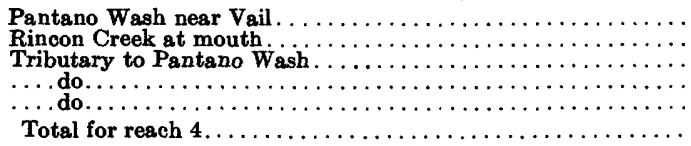 & $\begin{array}{r}457.0 \\
81.4 \\
31.9 \\
28.7 \\
6.2 \\
605.2\end{array}$ & $\begin{array}{r}75.6 \\
13.4 \\
5.3 \\
4.7 \\
1.0 \\
100.0\end{array}$ & $\begin{array}{r}21.5 \\
12.0 \\
9.8 \\
5.4 \\
0\end{array}$ \\
\hline
\end{tabular}

Reach 5. Tanque Verde and Rillito Creeks from Tanque Verde

5-1. Tanque Verde Creek at Sabino Canyon road

5-2. Ventana Canyon at mouth.

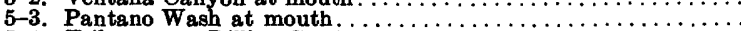

5-4. Tributary to Rillito Creek.

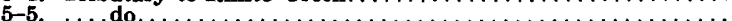

5-6. .... do.

5-7. .... do.

Total for reach 5

\begin{tabular}{rrr}
220.5 & 24.1 & 9.5 \\
14.5 & 1.6 & 9.0 \\
605.2 & 66.2 & 7.5 \\
13.2 & 1.4 & 6.4 \\
20.5 & 2.2 & 4.8 \\
16.5 & 1.8 & 2.6 \\
25.0 & 2.7 & 0 \\
\hline 915.4 & 100.0 & $\ldots$
\end{tabular}

Reach 6. Canada del Oro from the foothills of the Santa Catalina

6-1. Canada del Oro at base of mountains...............

6-2. Sutherland Wash.

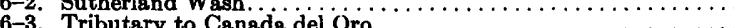

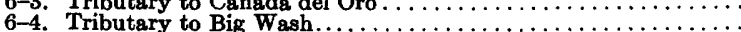

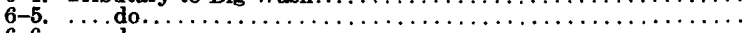

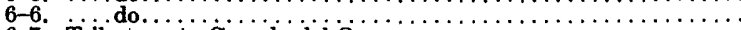

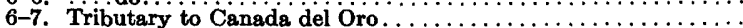

Total for reach 6 .

\begin{tabular}{rrr}
41.5 & 16.2 & 24.1 \\
37.0 & 14.5 & 11.2 \\
32.4 & 12.7 & 9.9 \\
35.8 & 14.0 & 21.9 \\
38.5 & 15.0 & 16.8 \\
36.1 & 14.1 & 9.9 \\
34.6 & 13.5 & 0 \\
\hline 255.9 & 100.0 & $\ldots \ldots \ldots$
\end{tabular}


streamflow and synthesized infiltration volumes (1936-63) for the channels, Tucson basin

\begin{tabular}{|c|c|c|c|c|c|c|c|c|}
\hline \multicolumn{3}{|c|}{ Average annual inflow } & \multicolumn{3}{|c|}{ Average annual infiltration! } & \multicolumn{3}{|c|}{$\begin{array}{l}\text { Average annual outflow at } \\
\text { end point of reach }\end{array}$} \\
\hline \multirow{2}{*}{ Acre-feet } & \multirow{2}{*}{$\begin{array}{l}\text { Acre- } \\
\text { feet per } \\
\text { sq mi }\end{array}$} & \multirow{2}{*}{$\begin{array}{l}\text { Percent- } \\
\text { age of } \\
\text { total }\end{array}$} & \multirow{2}{*}{ Acre-feet } & \multirow{2}{*}{$\begin{array}{l}\text { Percent- } \\
\text { age of } \\
\text { inflow }\end{array}$} & \multirow{2}{*}{$\begin{array}{l}\text { Percent- } \\
\text { age of } \\
\text { total } \\
\text { infiltra- } \\
\text { tion }\end{array}$} & $\begin{array}{l}\text { Inflow } \\
\text { infiltr }\end{array}$ & $\begin{array}{l}\text { ninus } \\
\text { tion }\end{array}$ & \multirow{2}{*}{$\begin{array}{l}\text { Measured } \\
\text { (acre- } \\
\text { feet) }\end{array}$} \\
\hline & & & & & & Acre-feet & $\begin{array}{l}\text { Percent- } \\
\text { age of } \\
\text { total } \\
\text { outflow }\end{array}$ & \\
\hline
\end{tabular}

from Continental to Tucson

\begin{tabular}{|c|c|c|c|c|c|c|c|c|}
\hline $\begin{array}{r}11,420 \\
1,670 \\
1,190 \\
1,780 \\
1,260 \\
1,780 \\
900 \\
830 \\
600 \\
1,020 \\
\end{array}$ & $\begin{array}{r}6.9 \\
18.2 \\
20.7 \\
16.8 \\
19.2 \\
17.7 \\
23.8 \\
24.1 \\
29.7 \\
21.2\end{array}$ & $\begin{array}{r}\mathbf{5 0 . 9} \\
\mathbf{7 . 4} \\
\mathbf{5 . 3} \\
\mathbf{7 . 9} \\
\mathbf{5 . 6} \\
\mathbf{7 . 9} \\
\mathbf{4 . 0} \\
\mathbf{3 . 7} \\
\mathbf{2 . 7} \\
\mathbf{4 . 6}\end{array}$ & $\begin{array}{r}\mathbf{5 , 3 6 0} \\
\mathbf{9 3 0} \\
\mathbf{6 8 0} \\
\mathbf{7 3 0} \\
\mathbf{5 1 0} \\
\mathbf{4 3 0} \\
220 \\
100 \\
60 \\
10\end{array}$ & $\begin{array}{l}46.9 \\
55.7 \\
57.1 \\
41.0 \\
40.5 \\
24.2 \\
24.4 \\
12.0 \\
10.0 \\
1.0\end{array}$ & $\begin{array}{r}59.4 \\
10.2 \\
7.5 \\
8.1 \\
5.7 \\
4.8 \\
2.4 \\
1.1 \\
.7 \\
.1\end{array}$ & $\begin{array}{r}6,060 \\
740 \\
510 \\
1,050 \\
750 \\
1,350 \\
680 \\
730 \\
540 \\
1,010 \\
\end{array}$ & $\begin{array}{r}45.2 \\
5.5 \\
3.8 \\
7.8 \\
5.6 \\
10.1 \\
5.1 \\
\mathbf{5 . 4} \\
4.0 \\
\mathbf{7 . 5} \\
\end{array}$ & 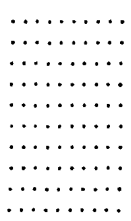 \\
\hline$\overline{22,450}$ & $\ldots \ldots \ldots$ & 100.0 & $\overline{9,030}$ & $\overline{40.2}$ & $\overline{100.0}$ & $\overline{13,420}$ & $\overline{100.0}$ & ${ }^{2} 13,310$ \\
\hline
\end{tabular}

to the Sabino Canyon road crossing of Tanque Verde Creek

\begin{tabular}{|c|c|c|c|c|c|c|c|c|}
\hline $\begin{array}{r}\mathbf{s}, \mathbf{3 6 0} \\
430 \\
800 \\
250 \\
820 \\
260 \\
29,150 \\
280 \\
\mathbf{3 9 0} \\
\end{array}$ & $\begin{array}{r}101.4 \\
25.0 \\
26.1 \\
30.1 \\
24.0 \\
29.2 \\
176.6 \\
24.6 \\
25.8\end{array}$ & $\begin{array}{r}26.0 \\
2.6 \\
4.8 \\
1.5 \\
4.9 \\
1.6 \\
54.6 \\
1.7 \\
2.3\end{array}$ & $\begin{array}{r}3,390 \\
250 \\
470 \\
90 \\
510 \\
90 \\
2,620 \\
120 \\
0\end{array}$ & $\begin{array}{l}77.8 \\
58.1 \\
58.8 \\
36.0 \\
62.2 \\
34.6 \\
28.6 \\
42.8 \\
0\end{array}$ & $\begin{array}{r}45.0 \\
3.3 \\
6.2 \\
1.2 \\
6.8 \\
1.2 \\
34.7 \\
1.6 \\
0\end{array}$ & $\begin{array}{r}970 \\
180 \\
330 \\
160 \\
310 \\
170 \\
6,530 \\
160 \\
390\end{array}$ & \begin{tabular}{r|}
10.6 \\
2.0 \\
3.6 \\
1.7 \\
3.4 \\
1.8 \\
71.8 \\
71.0 \\
1.7 \\
4.2
\end{tabular} & 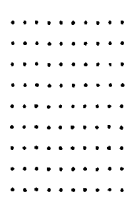 \\
\hline$\overline{16, \overline{740}}$ & $\ldots \ldots \ldots$ & $\overline{100.0}$ & $\overline{7,540}$ & $\overline{45.0}$ & $\overline{100.0}$ & $\overline{9,200}$ & $\overline{100.0}$ & 8,150 \\
\hline
\end{tabular}

station near Tucson to Pantano Wash

\begin{tabular}{|c|c|c|c|c|c|c|c|c|}
\hline $\begin{array}{r}32,610 \\
590 \\
590 \\
\end{array}$ & $\begin{array}{l}58.2 \\
32.2 \\
32.2\end{array}$ & $\begin{array}{l}68.8 \\
15.6 \\
15.6 \\
\end{array}$ & $\begin{array}{r}2,600 \\
450 \\
450 \\
\end{array}$ & $\begin{array}{l}99.6 \\
76.3 \\
76.3 \\
\end{array}$ & $\begin{array}{l}74.4 \\
12.8 \\
12.8 \\
\end{array}$ & $\begin{array}{r}10 \\
140 \\
140 \\
\end{array}$ & $\begin{array}{r}3.4 \\
48.3 \\
48.3 \\
\end{array}$ & $\begin{array}{l}\ldots \ldots \ldots \\
\ldots \ldots \ldots \ldots \\
\ldots \ldots \ldots \ldots\end{array}$ \\
\hline$\overline{3, \overline{790}}$ & $\ldots \ldots \ldots$ & $\overline{100.0}$ & $\overline{3,500}$ & $\overline{92.3}$ & $\overline{100.0}$ & $\overline{290}$ & $\overline{100.0}$ & $\ldots \ldots \ldots$ \\
\hline
\end{tabular}

station near Vail to Rillito Creek

\begin{tabular}{|c|c|c|c|c|c|c|c|c|}
\hline $\begin{array}{r}\mathbf{8 5 , 0 5 0} \\
290 \\
840 \\
740 \\
230 \\
\end{array}$ & $\begin{array}{r}11.0 \\
35.6 \\
26.3 \\
25.8 \\
37.1 \\
37.1\end{array}$ & $\begin{array}{r}70.5 \\
4.1 \\
11.8 \\
10.4 \\
3.2\end{array}$ & $\begin{array}{r}4,180 \\
270 \\
480 \\
230 \\
0\end{array}$ & $\begin{array}{r}82.8 \\
93.1 \\
57.1 \\
31.1 \\
0\end{array}$ & $\begin{array}{r}81.0 \\
5.2 \\
9.3 \\
4.5 \\
0\end{array}$ & $\begin{array}{r}870 \\
20 \\
360 \\
510 \\
230\end{array}$ & $\begin{array}{r}43.7 \\
1.0 \\
18.1 \\
25.6 \\
11.6\end{array}$ & 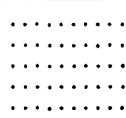 \\
\hline$\overline{7,150}$ & $\ldots \ldots \ldots$ & $\overline{100.0}$ & $\overline{5,160}$ & $\overline{72.2}$ & $\overline{100.0}$ & $\overline{1,990}$ & $\overline{100.0}$ & $\ldots$ \\
\hline
\end{tabular}

\section{Creek at Tucson to the Rillito Creek near Tucson gaging station}

\begin{tabular}{|c|c|c|c|c|c|c|c|c|}
\hline $\begin{array}{r}39,150 \\
480 \\
1,990 \\
460 \\
620 \\
520 \\
770 \\
\end{array}$ & \begin{tabular}{r|}
41.5 \\
33.1 \\
3.3 \\
34.8 \\
30.2 \\
31.5 \\
30.8
\end{tabular} & $\begin{array}{r}65.5 \\
\mathbf{3 . 4} \\
14.2 \\
\mathbf{3 . 3} \\
\mathbf{4 . 4} \\
\mathbf{3 . 7} \\
\mathbf{5 . 5}\end{array}$ & $\begin{array}{r}5,500 \\
420 \\
1,140 \\
290 \\
290 \\
140 \\
0\end{array}$ & $\begin{array}{l}60.1 \\
87.5 \\
57.3 \\
63.0 \\
46.8 \\
26.9 \\
0\end{array}$ & $\begin{array}{r}70.7 \\
5.4 \\
14.7 \\
3.7 \\
3.7 \\
1.8 \\
0\end{array}$ & $\begin{array}{r}3,650 \\
60 \\
850 \\
170 \\
330 \\
380 \\
770 \\
\end{array}$ & $\begin{array}{r}58.8 \\
1.0 \\
13.7 \\
2.7 \\
5.3 \\
6.1 \\
12.4 \\
\end{array}$ & $\begin{array}{l}\ldots \ldots \ldots \\
\ldots \ldots \\
\ldots \ldots \\
\ldots \ldots \\
\ldots \ldots \\
\ldots \ldots \ldots \\
\ldots \ldots \ldots\end{array}$ \\
\hline$\overline{13,990}$ & $\ldots \ldots \ldots$ & 100.0 & $\overline{7,780}$ & $\overline{55.6}$ & $\overline{100.0}$ & 6,210 & $\overline{100.0}$ & 26,080 \\
\hline
\end{tabular}

Mountains and 12 miles of Big Wash from Canada del Oro upstream

\begin{tabular}{|c|c|c|c|c|c|c|c|c|}
\hline $\begin{array}{r}\mathbf{5 , 0 2 0} \\
\mathbf{8 4 0} \\
\mathbf{7 5 0} \\
\mathbf{8 2 0} \\
\mathbf{8 9 0} \\
\mathbf{8 2 0} \\
\mathbf{8 0 0} \\
\end{array}$ & $\begin{array}{r}121 \\
23 \\
23 \\
23 \\
23 \\
23 \\
23\end{array}$ & $\begin{array}{r}50.6 \\
8.5 \\
7.5 \\
8.2 \\
9.0 \\
8.2 \\
8.0 \\
\end{array}$ & $\begin{array}{r}4,400 \\
240 \\
190 \\
490 \\
410 \\
210 \\
0 \\
\end{array}$ & $\begin{array}{l}87.6 \\
28.6 \\
25.3 \\
59.8 \\
46.0 \\
25.6 \\
0 \\
\end{array}$ & $\begin{array}{r}74.1 \\
4.0 \\
3.2 \\
8.2 \\
6.9 \\
3.6 \\
0 \\
\end{array}$ & $\begin{array}{l}620 \\
600 \\
560 \\
330 \\
480 \\
610 \\
800 \\
\end{array}$ & $\begin{array}{r}15.5 \\
15.0 \\
14.0 \\
8.2 \\
12.0 \\
15.3 \\
20.0 \\
\end{array}$ & $\begin{array}{l}\ldots \ldots \ldots \\
\ldots \ldots \\
\ldots \ldots \\
\ldots \ldots \\
\cdots \cdots \\
\ldots \ldots\end{array}$ \\
\hline$\overline{9,940}$ & $\ldots \ldots \ldots$ & $\overline{100.0}$ & $\overline{5,940}$ & $\overline{59.8}$ & $\overline{100.0}$ & 4,000 & $\overline{100.0}$ & $\ldots \ldots \ldots$ \\
\hline
\end{tabular}


TABLE 3.-Water budget of average annual measured or synthesized streamflow main channels,

\begin{tabular}{|c|c|c|c|}
\hline \multirow[b]{2}{*}{ Inflow point (see pl. 1) } & \multicolumn{2}{|c|}{ Drainage area } & \multirow{2}{*}{$\begin{array}{l}\text { Length } \\
\text { of reach } \\
\text { from } \\
\text { point of } \\
\text { inflow } \\
\text { to end } \\
\text { of reach, } \\
\text { in miles }\end{array}$} \\
\hline & $\mathrm{Sq} \mathbf{m i}$ & $\begin{array}{l}\text { Percent- } \\
\text { age of } \\
\text { total }\end{array}$ & \\
\hline \multicolumn{4}{|c|}{$\begin{array}{r}\text { Reach 7. Santa Cruz River from the gaging station at Tucson to tho gaging } \\
\text { gaging station near Tucson }\end{array}$} \\
\hline 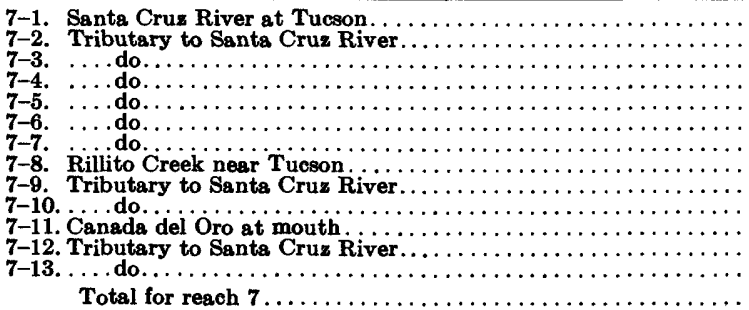 & $\begin{array}{r}2,222.0 \\
5.2 \\
13.3 \\
9.7 \\
15.6 \\
10.2 \\
9.1 \\
918.0 \\
19.4 \\
6.7 \\
256.0 \\
6.2 \\
11.9 \\
3,503.3\end{array}$ & $\begin{array}{r}63.4 \\
.1 \\
.4 \\
.3 \\
.4 \\
.3 \\
.3 \\
26.2 \\
.6 \\
.2 \\
7.3 \\
.2 \\
.3 \\
100.0\end{array}$ & $\begin{array}{r}12.25 \\
11.20 \\
11.20 \\
9.00 \\
6.50 \\
5.70 \\
4.80 \\
8.50 \\
5.70 \\
3.20 \\
2.60 \\
1.40 \\
1.40 \\
\cdots \cdots\end{array}$ \\
\hline
\end{tabular}

about 0.1 percent of the time, $120 \mathrm{cfs}$ about 0.5 percent of the time, $27 \mathrm{cfs}$ about 2.0 percent of the time, and $0.7 \mathrm{cfs}$ about 10 percent of the time. The data were used to develop a synthetic flow-duration curve for tributary-4 (fig. 11); similar computations were used to develop synthetic flow-duration curves for all the ungaged tributaries of the study reaches except for the upper part of Canada del Oro (tributary 6-1, pl. 1).

The synthetic flow-duration curve for the upper drainage of Canada del Oro (inflow point 6-1, pl. 1), which includes part of the northern slopes of the Santa Catalina Mountains, was estimated from the flow-duration curves for the Tanque Verde Creek near Tucson gaging station and the Sabino Creek near Tucson gaging station.

\section{INFILTRATION-DURATION CURVES}

Infiltration-duration curves for each inflow source were derived from the appropriate flow-duration curve and average inflow- to infiltration-rate relation. The infiltration rate determined for a given daily inflow rate was plotted on the infiltration-duration curve corresponding to the percent of time the given daily inflow rate occurred (fig. 11). Sufficient points were determined and plotted to define a smooth curve for the range of daily flows that occurred at the individual inflow points.

\section{BUDGET OF STREAMFLOW AND INFILTRATION VOLUMES}

The budget equation of streamflow in a length of losing river where the components $S_{1}{ }^{* * * * *} S_{7}$ denote volumes of (1) surface 
and synthesized infiltration volumes (1936-63) for the seven reaches of the Tucson basin-Continued

\begin{tabular}{|c|c|c|c|c|c|c|c|c|}
\hline \multicolumn{3}{|c|}{ Average annual inflow } & \multicolumn{3}{|c|}{ Average annual infiltration ${ }^{1}$} & \multicolumn{3}{|c|}{$\begin{array}{l}\text { Average annual outflow at } \\
\text { Santa Cruz River at Cortaro }\end{array}$} \\
\hline \multirow{2}{*}{ Acre-feet } & \multirow{2}{*}{$\begin{array}{l}\text { Acre- } \\
\text { feet per } \\
\text { sq mi }\end{array}$} & \multirow{2}{*}{$\begin{array}{l}\text { Percent- } \\
\text { age of } \\
\text { total }\end{array}$} & \multirow{2}{*}{ Acre-feet } & \multirow{2}{*}{$\begin{array}{l}\text { Percent- } \\
\text { age of } \\
\text { inflow }\end{array}$} & \multirow{2}{*}{$\begin{array}{l}\text { Percent- } \\
\text { age of } \\
\text { total } \\
\text { infiltra- } \\
\text { tion }\end{array}$} & \multicolumn{2}{|c|}{$\begin{array}{l}\text { Inflow minus } \\
\text { infiltration }\end{array}$} & \multirow{2}{*}{$\begin{array}{c}\text { Measured } \\
\text { (acre- } \\
\text { feet) }\end{array}$} \\
\hline & & & & & & Acre-feet & $\begin{array}{l}\text { Percent- } \\
\text { age of } \\
\text { total } \\
\text { outflow }\end{array}$ & \\
\hline
\end{tabular}

stations at Cortaro, including the 4.3 miles of reach of Rillito Creek from the to the Santa Cruz River

\begin{tabular}{|c|c|c|c|c|c|c|c|c|}
\hline $\begin{array}{r}213,310 \\
170 \\
440 \\
350 \\
480 \\
360 \\
350 \\
26,080 \\
490 \\
220 \\
4,000 \\
200 \\
400\end{array}$ & \begin{tabular}{|r|}
6.0 \\
33.0 \\
33.0 \\
37.0 \\
31.0 \\
35.0 \\
38.0 \\
6.6 \\
25.0 \\
33.0 \\
15.8 \\
33.0 \\
33.0
\end{tabular} & \begin{tabular}{r|}
49.5 \\
.6 \\
1.7 \\
1.3 \\
1.8 \\
1.3 \\
1.3 \\
22.6 \\
2.6 \\
1.9 \\
.8 \\
15.0 \\
.7
\end{tabular} & $\begin{array}{r}4,680 \\
120 \\
300 \\
200 \\
150 \\
100 \\
90 \\
1,730 \\
160 \\
40 \\
420 \\
10 \\
30\end{array}$ & $\begin{array}{r}35.2 \\
70.6 \\
68.2 \\
57.1 \\
31.2 \\
27.8 \\
25.7 \\
28.5 \\
32.7 \\
18.2 \\
10.4 \\
5.0 \\
7.5\end{array}$ & $\begin{array}{r}58.3 \\
1.5 \\
3.7 \\
2.5 \\
1.9 \\
1.2 \\
1.1 \\
21.6 \\
2.0 \\
.5 \\
5.2 \\
.1 \\
.4\end{array}$ & $\begin{array}{r}\mathbf{8 , 6 3 0} \\
50 \\
140 \\
150 \\
\mathbf{3 3 0} \\
260 \\
260 \\
4,350 \\
330 \\
180 \\
\mathbf{3 , 5 8 0} \\
190 \\
\mathbf{3 7 0}\end{array}$ & \begin{tabular}{r|}
45.8 \\
.3 \\
.7 \\
.8 \\
1.7 \\
1.4 \\
1.4 \\
23.0 \\
1.7 \\
1.0 \\
19.2 \\
1.0 \\
2.0
\end{tabular} & 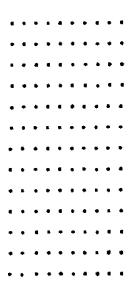 \\
\hline$\overline{26,850}$ & $\ldots \ldots \ldots$ & $\overline{100.0}$ & $\overline{8,030}$ & $\overline{29.9}$ & $\overline{100.0}$ & $\overline{18,820}$ & $\overline{100.0}$ & 218,990 \\
\hline
\end{tabular}

1 Net difference between volumes of precipitation on and evaporation from the flowing water is assumed negligible; therefore, the inflitration volume is taken as the volume of depletion of streamflow.

2 Measured.

3 Streamflow measured for part of period. (See table 1.)

channel is

$$
\sum_{j=1}^{7} S_{j}=0,
$$

flow in the river, (2) surface flow from tributaries, (3) precipitation on streamflow, (4) infiltration from streamflow, (5) evaporation from streamflow, (6) changes in surface storage, and (7) surface outflow. In this budget study the net difference between precipitation on and evaporation from the flowing water was assumed to be negligible. The average annual change in stream storage for the period 1936-63 was zero.

\section{INDIVIDUAL REACHES}

The water budget of average annual measured or synthesized streamflow volumes for the seven individual reaches is given in table 3 . In the budget, the infiltration volumes were obtained from infiltration-duration curves, and streamflow volumes were measured or were obtained from flow-duration curves.

Computation of the inflow and infiltration volumes was made by summing 30 or more incremental products-increments of time multiplied by the average rate of inflow or infiltration during the time increments. The 30 increments of time were of different 
duration and were selected to give almost equal incremental volumes of flow. In approximating the average annual volume of infiltration, the infiltration from water which enters the reaches through the main channels and the infiltration from water from tributary basins were computed separately.

The determination of infiltration volumes from each source independently may have introduced bias into the estimates of infiltration; however, the errors may be small (compared to other possible errors) for several reasons: (1) The distribution of runoff-producing thunderstorms is erratic, both areally and in time; thus, runoff from an individual local thunderstorm in a tributary basin probably will not coincide with runoff from a thunderstorm in another part of the total contributing basin. (2) The shape of the basin is such that most of the runoff produced in small local tributary watersheds as a result of general or frontal storms will pass through the study reach before runoff produced as a result of the same storm in the main part of the contributing basin will pass through the study reach. (3) The rate of change of infiltration in cubic feet per second relative to the rate of change in discharge in cubic feet per second probably is not great; consequently, errors introduced by treating the flows separately according to source would be small. (4) There are some compensating errors. The bias probably would cause the estimates of average annual infiltration to be slightly larger than actual infiltration.

Another possible source of bias results from applying the average inflow to infiltration relation, defined largely by using data obtained from storm events, to flow-duration curves which were defined by using average daily flows. This application would probably cause the estimates of infiltration to be smaller than actual infiltration and thus would have a tendency to compensate for the bias that is described in the preceding paragraph.

The outflow synthesized from the budget was compared directly with the measured outflow in reaches 1,5 , and 7 .

\section{COMPOSITE FOR THE SEVEN REACHES}

A water budget was computed for the composite average annual inflow, infiltration, and outflow volumes for the main channels of the Tucson basin. The average annual inflow volumes were computed from measured flow or were computed from synthesized flowduration curves for different locations along the streams. The total average annual volume of infiltration is the sum of the infiltration that occurred in the reach in which the inflow originated plus that which occurred as the water moved through subsequent reaches en route to the downstream end of the basin. After com- 
puting the average annual infiltration volume for the first reach, the volumes for the remaining reaches were obtained by multiplying the remaining inflow volume after upstream depletion by the average percentage of depletion of the combined flows as the water moved downstream. For example, the average annual inflow for Santa Cruz River at Continental, was about 11,400 acrefeet; of this amount, about 5,400 acre-feet per year was depleted by infiltration within reach 1 (table 3 ). The outflow from reach 1 resulting from this source of inflow was about 6,000 acre-feet per year (table 3 ). The average volume of flow from all sources at the gaging station at Tucson was about 13,300 acre-feet annually, of which about 4,700 acre-feet or 35 percent was depleted by infiltration en route to Cortaro. To find the amount of infiltration in reach 7 for the "Santa Cruz River at Continental" multiply 6,000 acre-feet by 35 percent to obtain about 2,100 acre-feet. Then, the average annual volume of infiltration within the Tucson basin from surface flow in the Santa Cruz River at Continental would be about 5,400 acre-feet plus 2,100 or 7,500 acre-feet. The average annual streamflow in the Santa Cruz River at Cortaro included about 3,900 acre-feet of water that originated in the watershed above Continental.

The main channels of the Tucson basin are efficient natural infiltration galleries. The average annual inflow to the seven reaches of the main channels was about 66,000 acre-feet per year for the period 1936-63, of which about 47,000 acre-feet or about 70 percent was depleted by infiltration within the basin; the outflow was about 19,000 acre-feet annually (table 4). A larger percentage (about 80 percent) of depletion of flows originated in the relatively large drainage basins above the Santa Cruz River at Continental, at Tanque Verde Creek near Tucson, at Sabino Creek near Tucson, at Bear Creek near Tucson, at Pantano Wash near Vail, and at Rincon Creek near Tucson gaging stations. About 50 percent of the average annual inflow was measured at these stations (table 4 ), and 50 percent was calculated by using the derived relation between discharge and size of basin.

About 70 percent of the total depletion of streamflow in the main channels occurred in reaches $1,2,5$, and 7 . The percentage of the total of the average annual infiltration volumes occurring in individual reaches is given in table 5 . The average annual infiltration volumes per mile of channel in the seven reaches also are given.

In addition to the seven reaches, estimates of average annual infiltration were made for the Santa Cruz River from the southern 
TABLE 4.-Water budget of average annual synthesized streamflow and

\begin{tabular}{|c|c|c|c|}
\hline \multirow[b]{2}{*}{ Inflow point (see pl. 1) } & \multicolumn{2}{|c|}{ Drainage area } & \multirow{2}{*}{$\begin{array}{l}\text { Length } \\
\text { of reach } \\
\text { from } \\
\text { point of } \\
\text { inflow } \\
\text { to end } \\
\text { of reach, } \\
\text { in miles }\end{array}$} \\
\hline & Sq mi & $\begin{array}{l}\text { Percent- } \\
\text { age of } \\
\text { total }\end{array}$ & \\
\hline 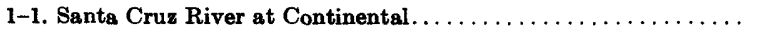 & $1,662.0$ & 47.5 & 40.75 \\
\hline $\begin{array}{l}\text { 1-2 to 1-10. Ungaged tributaries to Santa Cruz River from } \\
\text { Continental to Tucson. }\end{array}$ & 560.0 & 16.0 & \\
\hline 2-1. Tanque Verde Creek near Tucson $\ldots \ldots \ldots \ldots \ldots \ldots$ & 43.0 & 1.2 & 28.5 \\
\hline 2-7. Sabino and Bear Creeks near Tucson $\ldots \ldots \ldots \ldots \ldots \ldots \ldots$ & 51.8 & 1.5 & 22.0 \\
\hline $\begin{array}{l}2-2 \text { to } 2-6,2-8,2-9 . \text { Ungaged tributaries to Tanque Verde Creek } \\
\text { from gaging station near Tucson to Sabino Canyon road. }\end{array}$ & 125.7 & 3.6 & \\
\hline 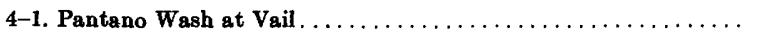 & 457.0 & 13.0 & 37.5 \\
\hline 3-1. Rincon Creek near Tucson $\ldots \ldots \ldots \ldots \ldots \ldots \ldots \ldots \ldots$ & 44.8 & 1.3 & 35.8 \\
\hline $\begin{array}{l}\text { 3-2, 3-3. Ungaged tributaries to Rincon Creek from gaging station } \\
\text { to mouth. }\end{array}$ & 36.6 & 1.0 & $\cdots$ \\
\hline $\begin{array}{l}\text { 4-3 to 4-5. Ungaged tributaries along Pantano Wash from Vail } \\
\text { to mouth. }\end{array}$ & 66.8 & 1.9 & \\
\hline $\begin{array}{l}\text { 5-2 to 5-7. Ungaged tributaries to Rillito Creek from Sabino Canyon } \\
\text { road to gaging station near Tucson. }\end{array}$ & 89.7 & 2.6 & \\
\hline 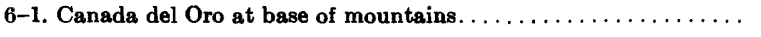 & 41.5 & 1.2 & 26.7 \\
\hline $\begin{array}{l}\text { 6-2 to 6-7. Ungaged tributaries of Canada del Oro from base of } \\
\text { mountains to mouth. }\end{array}$ & 214.4 & 6.1 & $\cdots$ \\
\hline $\begin{array}{l}\text { 7-2 to 7-13. Ungaged tributaries to Santa Cruz River from Tucson } \\
\text { to Cortaro. }\end{array}$ & 107.1 & 3.1 & \\
\hline Composite of all reaches $\ldots \ldots \ldots \ldots \ldots \ldots \ldots \ldots \ldots \ldots$ & $3,500.4$ & 100.0 & \\
\hline
\end{tabular}

1 Net difference between volumes of precipitation on and evaporation from the flowing water is assumed negligible; therefore, the infiltration volume is taken as the volume of depletion of streamfiow.

2 Measured.

boundary of Pima County to the gaging station at Continental, and for the Santa Cruz River from the gaging station at Cortaro to Rillito. In the upstream reach, the average annual infiltration per mile of channel was assumed to be the same as the average annual infiltration per mile occurring in reach 1 ; thus, about 3,200 acrefeet per year infiltrated the 10-mile reach. In the downstream reach, the average annual infiltration per mile of channel was assumed to be the same as that occurring in reach 7; thus, about 2,600 acre-feet per year infiltrated the 5.5-mile reach.

\section{VARIATION OF ANNUAL INFILTRATION VOLUMES}

The annual variation in infiltration volume in the main channels of the Tucson basin is large and mainly is the result of variations in streamflow. The slopes of duration curves are quantitative measures of variation; a steep slope indicates a large variation with time, and a gentle slope indicates a small variation with time. Because the average slope of the infiltration-duration curve is less than the average slope of the flow-duration curve 
infiltration volumes for the main channels of the Tucson basin (1936-63)

\begin{tabular}{|c|c|c|c|c|c|c|c|c|}
\hline \multicolumn{3}{|c|}{ Average annual intlow } & \multicolumn{3}{|c|}{ Average annual infiltration ${ }^{1}$} & \multicolumn{3}{|c|}{$\begin{array}{l}\text { Average annual outflow at } \\
\text { Santa Cruz River at Cortaro }\end{array}$} \\
\hline \multirow{2}{*}{ Acre-feet } & \multirow{2}{*}{$\begin{array}{l}\text { Acre- } \\
\text { feet per } \\
\text { sq mi }\end{array}$} & \multirow{2}{*}{$\begin{array}{l}\text { Percent- } \\
\text { age of } \\
\text { total }\end{array}$} & \multirow{2}{*}{ Acre-feet } & \multirow{2}{*}{$\begin{array}{l}\text { Percent- } \\
\text { age of } \\
\text { inflow }\end{array}$} & \multirow{2}{*}{$\begin{array}{l}\text { Percent- } \\
\text { age of } \\
\text { total } \\
\text { infiltra- } \\
\text { tion }\end{array}$} & \multicolumn{2}{|c|}{$\begin{array}{l}\text { Inflow minus } \\
\text { infiltration }\end{array}$} & \multirow{2}{*}{$\begin{array}{c}\text { Measured } \\
\text { (acre- } \\
\text { feet) }\end{array}$} \\
\hline & & & & & & Acre-feet & $\begin{array}{l}\text { Percent- } \\
\text { age of } \\
\text { total } \\
\text { outflow }\end{array}$ & \\
\hline 211,420 & 6.9 & 17.3 & 7,490 & 65.6 & 15.9 & 3,930 & 20.6 & .. \\
\hline 11,030 & $\ldots \ldots$ & 16.7 & 6,260 & 56.8 & 13.3 & 4,770 & 25.1 & \\
\hline 24,360 & 101.0 & 6.6 & 4,080 & 93.6 & 8.7 & 280 & 1.5 & \\
\hline 29,150 & 177.0 & 13.9 & 7,280 & 79.6 & 15.5 & 1,870 & 9.8 & $\ldots$ \\
\hline 3,230 & $\ldots \ldots \ldots$ & 4.9 & 2,740 & 84.8 & 5.8 & 490 & 2.6 & $\ldots \ldots \ldots$ \\
\hline 25,050 & 11.0 & 7.7 & 4,780 & 94.2 & 10.1 & 270 & 1.5 & $\ldots \ldots \ldots$ \\
\hline 22,610 & 58.2 & 3.9 & 2,610 & 100.0 & 5.5 & $\mathbf{0}$ & $\mathbf{0}$ & \\
\hline 1,180 & $\ldots \ldots \ldots$ & 1.8 & 1,180 & 100.0 & 2.5 & 0 & 0 & . \\
\hline 1,810 & $\cdots$ & 2.7 & 1,470 & 81.2 & 3.1 & 340 & 1.8 & $\ldots \ldots \ldots$ \\
\hline 2,850 & $\ldots \ldots \ldots$ & 4.3 & 1,630 & 57.2 & 3.5 & 1,220 & 6.4 & $\ldots \ldots \ldots$ \\
\hline 5,020 & 121.0 & 7.6 & 4,460 & 88.8 & 9.5 & 560 & 2.9 & $\ldots \ldots \ldots \ldots$ \\
\hline 4,920 & $\ldots \ldots \ldots$ & 7.4 & 1,880 & 38.2 & 4.0 & 3,040 & 16.0 & ........ \\
\hline $\begin{array}{r}3,460 \\
66,090\end{array}$ & $\ldots \ldots \cdots$ & $\begin{array}{r}5.2 \\
100.0\end{array}$ & $\begin{array}{r}1,220 \\
47,080\end{array}$ & $\begin{array}{l}35.3 \\
71.2\end{array}$ & $\begin{array}{r}2.6 \\
100.0\end{array}$ & $\begin{array}{r}2,240 \\
19,010\end{array}$ & $\begin{array}{r}11.8 \\
100.0\end{array}$ & ${ }_{218,990}$ \\
\hline
\end{tabular}

TABLE 5.-Percentage of total average annual infiltration of inflow in the seven reaches, 1936-63

\begin{tabular}{rrccc}
\hline Reach & $\begin{array}{c}\text { Length of } \\
\text { channel in } \\
\text { miles }\end{array}$ & $\begin{array}{c}\text { Percentage of } \\
\text { inflow to } \\
\text { reach }\end{array}$ & $\begin{array}{c}\text { Percentage of total } \\
\text { average annual } \\
\text { infiltration in } \\
\text { the seven } \\
\text { reaches }\end{array}$ & $\begin{array}{c}\text { Average annual } \\
\text { infiltration, in } \\
\text { acre-feet per } \\
\text { year per mile } \\
\text { of channel }\end{array}$ \\
\hline $1 \ldots \ldots \ldots \ldots \ldots \ldots \ldots$ & 28.5 & 40.2 & 19.2 & 320 \\
$2 \ldots \ldots \ldots \ldots \ldots \ldots \ldots \ldots$ & 117.5 & 45.0 & 16.0 & 430 \\
$3 \ldots \ldots \ldots \ldots \ldots \ldots \ldots$ & 7.8 & 92.3 & 7.4 & 450 \\
$4 \ldots \ldots \ldots \ldots \ldots \ldots \ldots$ & 21.5 & 72.2 & 11.1 & 240 \\
$5 \ldots \ldots \ldots \ldots \ldots \ldots \ldots$ & 9.5 & 55.6 & 16.6 & 820 \\
$6 \ldots \ldots \ldots \ldots \ldots \ldots \ldots$ & 236.1 & 59.8 & 12.6 & 160 \\
$7 \ldots \ldots \ldots \ldots \ldots \ldots \ldots$ & 316.6 & 29.9 & 17.1 & 480 \\
\hline Total. $\ldots \ldots \ldots$ & 137.5 & 71.2 & 100.0 & 340 \\
\hline
\end{tabular}

1 Includes 3 miles of Sabino Creek and 4 miles of Agua Caliente Wash.

2 Includes 12 miles of Big Wash.

3 Includes 4.3 miles of Rillito Creek.

(fig. 11), the variation of infiltration is assumed to be less than the variation of streamflow. The coefficient of variation is the ratio of the standard deviation to the mean. The coefficients of variation of the annual streamflow in the main channels of the Tucson basin 
range from 0.80 to 1.00 ; the coefficients of variation of annual infiltration in the main channels probably are less than the values for streamflow. Preliminary studies indicate that an average coefficient of variation of annual volumes of infiltration is about 0.7. On the basis of streamflow data, the extremes in the annual volumes of infiltration for the different reaches are estimated to range from near zero to more than four times the average annual volumes of infiltration in the reaches.

\section{ACGURACY OF THE GOMPUTED AVERAGE ANNUAL INFILTRATION DATA}

Because there are no continuous records for infiltration measured independently from streamflow, the accuracy of the average annual infiltration volumes for the $1936-63$ period could not be determined. However, by simple comparisons and deductive reasoning, the probable error in the data of infiltration is estimated to be less than 15 percent of the computed average annual infiltration volumes.

\section{REGULATION OF STREAMFLOW TO INCREASE INFILTRATION}

Infiltration in the main channels of the Tucson basin could be increased by regulating surface flow; however, the increase probably would be small unless the surface-water inflow is increased. If inflow is not increased, the maximum possible average annual increase in infiltration would be equal to the average annual outflow from the basin. The average outflow from the basin was about 19,000 acre-feet annually for the period 1936-63, but the annual outflow ranged from 1,800 to 67,390 acre-feet. The outflow of 19,000 acre-feet is about 40 percent of the computed average an-

TABLE 6.-Maximum possible increase in infiltration by total regulation of inflow from different sources in the Tucson basin

\begin{tabular}{|c|c|c|c|c|c|}
\hline \multirow[b]{2}{*}{$\begin{array}{l}\text { Inflow point } \\
\text { (see pl. 1) }\end{array}$} & \multicolumn{2}{|c|}{$\begin{array}{c}\text { Average annual } \\
\text { inflow, in acre-feet }\end{array}$} & \multicolumn{2}{|c|}{$\begin{array}{l}\text { Maximum possible increase } \\
\text { in infiltration, in percent }\end{array}$} & \multirow{2}{*}{$\begin{array}{c}\text { Decrease in } \\
\text { average annual } \\
\text { outflow at } \\
\text { Cortaro } \\
\text { if inflow is } \\
\text { totally regulated, } \\
\text { in percent }\end{array}$} \\
\hline & $\begin{array}{c}\text { At } \\
\text { source }\end{array}$ & $\begin{array}{l}\text { Source } \\
\text { water } \\
\text { reaching } \\
\text { Cortaro }\end{array}$ & $\begin{array}{c}\text { Increase divided } \\
\text { by infiltration } \\
\text { occurring } \\
\text { naturally from } \\
\text { water at } \\
\text { inflow point }\end{array}$ & $\begin{array}{l}\text { Increase divided } \\
\text { by infiltration } \\
\text { occurring } \\
\text { naturally in the } \\
\text { seven reaches }\end{array}$ & \\
\hline $\begin{array}{c}\text { 1-1. Santa Cruz River at } \\
\text { Continental........ } \\
\text { 2-1. Tanque Verde Creek }\end{array}$ & 111,420 & 3,930 & 52.5 & 8.3 & 20.7 \\
\hline $\begin{array}{r}\text { near Tucson....... } \\
\text { 2-7. Sabino Creek and Bear }\end{array}$ & 14,360 & 280 & 6.6 & .6 & 1.5 \\
\hline Creek at confluence. & 19,150 & 1,870 & 25.7 & 4.0 & 9.8 \\
\hline $\begin{array}{l}\text { 4-1. Pantano Wash at Vail. } \\
\text { 6-1. Canada del Oro at }\end{array}$ & $\mathbf{1 5 , 0 5 0}$ & 270 & 5.6 & .6 & 1.4 \\
\hline base of mountain... & 5,020 & 560 & 12.6 & 1.2 & 2.9 \\
\hline Remaining small tributaries. & 31,090 & 12,100 & 63.7 & 25.7 & 63.7 \\
\hline Total ........... & 66,090 & 19,010 & $\ldots \ldots \ldots \ldots \ldots$ & 40.4 & 100.0 \\
\hline
\end{tabular}

1 Measured. 
nual infiltration of 47,000 acre-feet, which occurs under natural conditions (table 4). The amount of additional infiltration that could have been induced by the total regulation of inflows from $1936-63$ is shown in table 6.

Maximum potential infiltration is almost impossible to achieve. The total regulation of inflow may decrease infiltration in some places and increase it in others. For example, total regulation may cause the deposition of fine sediment in the stream channel and thus decrease permeability of the channel material, which would decrease infiltration and change the hydraulic geometry of the stream-the width, depth, and velocity. The elimination of the flushing action of the high rates of moderately clear water from the Sabino, Bear, and Tanque Verde watersheds may result in the channel of Rillito Creek being bounded with fine material carried in from Pantano Wash and other tributaries. Conversely, the regulation of flows from Pantano Wash may effect an increase in infiltration in Rillito Creek during flow events from the Sabino, Bear, and Tanque Verde watersheds.

In some places, regulation of inflow and the resulting increase in infiltration would, in time, cause the water table to rise to the level of the streambed; infiltration would decrease, and evapotranspiration losses probably would increase. Rillito and Tanque Verde Creeks upstream from Dodge Blvd. are places where this condition might occur because there the reach is underlain by thin permeable alluvium, and the available storage space for water is relatively small. Under present conditions, evapotranspiration losses probably are high, but the additional input of water probably would result in perennial flow and even higher losses in evapotranspiration. Evapotranspiration can be minimized by regulating the surfacewater flow in order to increase infiltration along an alluvial channel, and by managing the ground-water system in such a way that an unsaturated volume of alluvium is available for storage.

If additional streamflow were available, the average annual infiltration along the main channels could be increased several times. At the present, the streams carry water only about 10 percent of the time, and the alluvial deposits could store large amounts of additional water. It would be necessary, however, to regulate the addition of surface water and the pumping of ground water to maintain infiltration at an optimum rate.

\section{SUMMARY}

Approximations were made of the average annual volumes of infiltration for the period 1936-63 by use of inflow- to infiltrationrate relations and flow duration of streamflow along the main 
channels in the Tucson basin. Streamflow data from gaging stations within or near the Tucson basin and miscellaneous discharge measurements were used in the analyses. In approximating the infiltration, the difference between the precipitation on and the evaporation from the flowing water is assumed negligible. Because no changes occurred in streamflow storage, the average annual volume of infiltration was taken as the average annual volume of depletion of streamflow. The empirical equation for the average relation between inflow rates and infiltration rates is

in which

$$
Q_{f}=C\left(Q_{\text {inflow }}\right)^{0.8} \text {, }
$$

$Q_{f} \quad=$ infiltration rate, which is the difference between the surface-water inflow and outflow rates during corresponding time intervals in a reach, in cubic feet per second,

$C=$ a variable coefficient, and

$Q_{\text {inflow }}=$ surface-water inflow rate, in cubic feet per second.

In the equation an average coefficient was determined or estimated for all flow moving through a given length of channel. Flowduration curves were derived using measured flows or the size of basin to discharge relations.

The main channels in the Tucson basin are efficient natural infiltration galleries. The average annual streamflow depletion ranged from about 30 to 90 percent of the average annual inflow to the seven reaches (table 7). The average annual inflow to all the reaches was about 66,000 acre-feet, of which about 47,000 or 70 percent was depleted by infiltration and about 19,000 acre-feet flowed out of the basin. About $\mathbf{7 0}$ percent of the average annual infiltration occurred in reaches $1,2,5$, and 7 (pl. 1).

The annual variation in infiltration volumes along the main channels is large and is mainly the result of variation in streamflow. On the basis of streamflow data, the extremes in the annual volumes of infiltration are estimated to range from near zero to more than four times the average annual volume. The accuracy of the computed average annual volume of infiltration cannot be determined from the available data; however, the probable error is estimated to be less than 15 percent of the computed average annual infiltration volume.

Infiltration could be increased by regulating surface-water flow, but the increase probably would be small unless inflow were increased. For the period 1936-63 the maximum possible annual increase in infiltration over that which occurred naturally would have been about 19,000 acre-feet, which was the average annual 

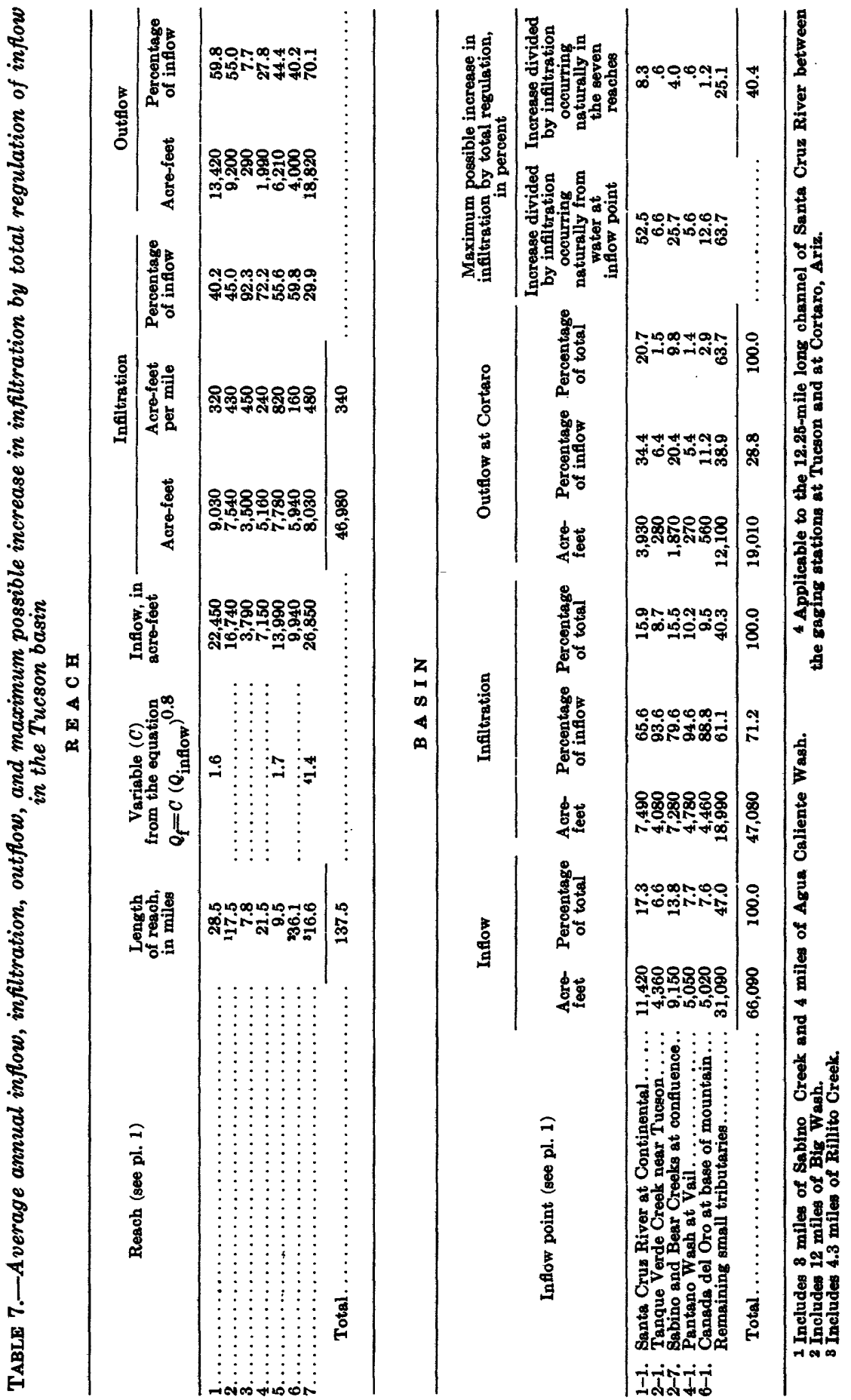
outflow from the basin (table 7). Maximum potential infiltration, however, would be almost impossible to achieve, and regulation might cause several changes that would tend to decrease infiltration. If flow is regulated to increase infiltration along a streambed having alluvium of limited storage capacity, the ground-water system must be managed as an integral part of the project.

If additional streamflow were available, the average annual infiltration along the main channels could be increased several times. At present, the streams carry water only about 10 percent of the time, and the alluvial deposits could store large amounts of additional water. It would be necessary, however, to regulate the addition of surface water and pumping of ground water in order to maintain infiltration at an optimum rate.

\section{LITERATURE GITED}

Burkham, D. E., 1970, A method for relating infiltration rates to streamflow rates in perched streams, in Geological Survey research 1970: U.S. Geol. Survey Prof. Paper 700-D [in press]. 